\title{
Ruderal vegetation of Kyiv City. I. Class Stellarietea mediae Tx. et al. in Tx. 1950
}

\author{
Dmytro V. DUBYNA (D), Svitlana M. IEMELIANOVA* (D), Tetiana P. DZIUBA (D), Natalia S. YEREMENKO (i), \\ Pavlo A. TYMOSHENKO (D) \\ M.G. Kholodny Institute of Botany, National Academy of Science of Ukraine 2, Tereschenkivska Str., Kyiv 01601, Ukraine
}

\begin{abstract}
This article, which is the first contribution in a series on the ruderal vegetation of the city of Kyiv, presents results of our studies of Stellarietea mediae plant communities occurring in the city. Their current state and phytocoenotic diversity has been determined. Based on modern methods of statistical data analyses, a classification scheme of Stellarietea mediae vegetation in the study area was developed and the leading factors of territorial and ecological differentiation of phytocoenoses were identified. It has been established that within Kyiv City, this class is represented by 24 associations and 3 basal communities belonging to 8 alliances and 4 orders. Their territorial distribution determines the types and intensity of anthropogenic disturbances, as well as the types of soil and its mechanical structure. Selected syntaxa are characterized and compared with their equivalents from other areas of Ukraine. It has been found that the main differences are at the level of co-occurring species, the composition of which mostly correlates with the types of anthropogenic disturbances and availability of water and mineral nutrients. According to the results of the ordination, it has been found that the distribution patterns of plant communities of Stellarietea mediae occur along the salt regime gradient of the edaphotope, as well as of ombro-, cryo-, and thermal regimes of the climate. Based on the phytoindication analysis, the ecological optimums of the plant communities in relation to the leading ecological factors were determined. The performed research supplements the available information about the presence and distribution of such associations as: Digitarietum ischaemii, Setario viridis-Erigeronetum canadensis, and Ambrosietum artemisiifoliae, in the territory of Ukraine. The proposed syntaxonomic scheme should become a basis of typological developments for strategic planning and practical implementation of activities for optimizing the urban environment and for sustainable development of the Kyiv urban agglomeration.
\end{abstract}

Keywords: ordination, phytoindication, syntaxonomy, Ukraine, urboecosystems

Supplementary Materials. Electronic Supplement (Table E1, e1) is available in the online version of this article et: https://ukrbotj.co.ua/archive/78/3/176

Article history. Submitted 28 September 2020. Revised 06 April 2021. Published 29 June 2021

Citation. Dubyna D.V., Iemelianova S.M., Dziuba T.P., Yeremenko N.S., Tymoshenko P.A. 2021. Ruderal vegetation of Kyiv City. I. Class Stellarietea mediae Tx. et al. in Tx. 1950. Ukrainian Botanical Journal, 78(3): 176-200.

*Corresponging author (e-mail: yemelianova.sv@gmail.com)

\section{Introduction}

Under the modern conditions of environmental reclaiming and large-scale transformations of natural landscapes, there are significant changes in indigenous plant communities, and these changes have the tendency to accelerate. This is directly reflected in the structure of the vegetation cover, in particular in urban areas where novel ruderal phytocoenoses are formed; they are adapted to the growing human impact and tolerant to the constant influence of various destructive factors.

Ruderal vegetation has a special functional and ecological importance in urban ecosystems. Developed on ecotopes newly formed as a result of human activity, it stabilizes disturbed substrates, starts succession series in demutation processes, and also participates in biogeochemical cycles (Dubyna et al., 2018). Ruderal phytocoenoses, adsorbing industrial emissions and

(C) 2021 D.V. Dubyna, S.M. Iemelianova, T.P. Dziuba, N.S. Yeremenko, P.A. Tymoshenko. Published by the M.G. Kholodny Institute of Botany, NAS of Ukraine. This is an open access article under the terms of the Creative Commons Attribution License (http://creativecommons.org/licenses/ by/4.0/), which permits use, distribution, and reproduction in any medium, provided the original work is properly cited 
accumulating salts of heavy metals and other chemical compounds, are considered to be an integral part of "natural systems" of air and soil refinement (Ishbirdin et al., 1988). At the same time, plant communities formed as a result of anthropogenic impact are centers of dispersal and invasions of alien species, including dangerous ones (such as invasive environmental weeds, potentolial crop weeds, etc.), with high invasive ability within and outside cities, which form a real threat to the biodiversity components of natural ecosystems. Ruderal plant communities are also a source of allergens that significantly worsen the quality of citizens' life. In this regard, studies of ruderal vegetation, in particular its composition, structural and functional features, territorial distribution, spatial dynamics, and measures of restructurization and optimization, are of urgent and top priority.

The studies of phytocoenoses of Ukrainian cities, in particular their syntaxonomic diversity, still remain rather fragmentary and insufficient in their scope and coverage. Phytosociological investigations of the vegetation of Ukraine have been conducted for a long time, using the dominant approach in which ruderal plant communities could not be classified. The object of research, in particular in urban areas, was mostly natural vegetation, taking into consideration the necessity of its priority inventorying for preservation under conditions of both the existing threats and potential dangers.

In Ukraine, the first studies of and publications on urban vegetation, based on the principles of Braun-Blanquet's school, appeared in the 1990s. There were studied ruderal plant communities of Chernihiv (Papucha, 1991), Lviv (Kucheryavyi et al., 1991), Yalta (Levon, 1999), and Simferopol (Epikhin, 2006). Later, results of studies spontaneous vegetation were published for several cities and towns, in particular, Cherkasy (Osypenko, 2006), Melitopol (Bredikhina, 2015), Kryvyi Rih (Smetana, 2002; Yeremenko, 2018), Pereyaslav-Khmelnytskyi (Dziuba, Solomakha, Tymoshenko, 2010), partly also of Ivano-Frankivsk (Tsap'yuk, 2012) and Chernivtsi (Tokaryuk, 2019). However, the vegetation cover of large urban agglomerations, where human impact is especially diverse and intense, and the processes of transformation are more distinct and accelerated in time, has not been investigated.

Among the large cities, Kyiv has a special place as the largest urban ecosystem of Ukraine, which is characterized by the uniqueness of its natural conditions and, at the same time, by intensive development of its economic infrastructure, housing and industrial development and construction, and growing population. The territory of the city $\left(835.6 \mathrm{~km}^{2}\right)$ is located on the border of the forest-steppe and forest zones on both banks of the Dnipro (Dnieper) River. Orographically, the right-bank part of the city is a raised plateau-like plain (with some parts, especially in the northern and southern outskirts, located within the floodplain), while the left-bank part is mainly a lowland formed by the floodplain and low terraces of the Dnipro River valley. The climate of the territory is temperate continental with warm summers and mild winters. The soil cover is dominated by turfpodzolic, gray forest soils, and chornozems (chernozems, black soil) (Stetsyuk et al., 2001). The specificity of natural conditions determines the peculiarities of the city's ecosystems, in particular, special features of their vegetation, including ruderal one.

Within the Kyiv urban agglomeration, floristic research was conducted in more detail (Yavorska, Mosyakin, 2001; Mosyakin, Yavorska, 2002; Grechyshkina, 2010, etc.). The phytocoenotic structure of vegetation was the object of several studies, most of which concerned natural plant communities of protected areas (Didukh, Chumak, 1992; Onyshchenko, 2011, 2013a, b; Kozyr, 2012, 2013; Goncharenko, Holyk, 2015; Holyk, Goncharenko, 2017; Kozyr et al., 2017; Goncharenko et al., 2020). Anthropogenic vegetation in Kyiv has been studied fragmentally within some areas or ruderal ecotopes. Sometimes, the objects of studies were specific coenoses. Thus, the ruderal vegetation of the Dnipro islands was studied by Tsukanova (2005), lawns - by Melezhik (Chokha, 2005), plant communities of the railways - by Dziuba and co-authors (Dziuba et al., 2019). Phytocoenoses of annual cereals were researched by Pashkevych (2012), communities with Elytrigia repens (L.) Nevski - by Oliynyk and Gubar (2019). Goncharenko and Yatsenko (2020) conducted partial investigations of the class Robinietea Jurko ex Hadač et Sofron 1980.

In 2016-2020, the authors carried out special geobotanical studies of ruderal vegetation in the administrative-territorial districts of Kyiv City to determine syntaxonomic diversity patterns within these districts and territorial distribution of plant communities and their ecological differentiation. This publication, which covers only the class Stellarietea mediae Tx. et al. in Tx. 1950, starts a series of works on the syntaxonomy of ruderal vegetation of Kyiv. It will be completed with a generalized publication on the differentiation of ruderal vegetation within the city, its typology, zoning, and methodical guidelines for constructive optimization. 


\section{Material and methods}

The basic material for our analysis consisted of 1621 relevés made by the authors in 2016-2020. After processing the general dataset with the JUICE software (Tichý, 2002), 452 relevés were assigned to the Stellarietea mediae class. They were further analyzed in detail to develop syntaxonomy and establish the leading factors of ecological differentiation. All relevés were made according to the Braun-Blanquet approach (Braun-Blanquet, 1964) on plots of $10-25 \mathrm{~m}^{2}$. Some plant communities, in particular small ones, were described from the whole area they occupied. Estimation of quantitative participation of species in stands was carried out using Mirkin's modified cover scale (Mirkin et al., 1989), where "+" - less than 1\%, "1" - 1-5\%, "2" 6-15\%, "3" - 16-25\%, "4" - 26-49\%, "5" - 50\% and more.

All vegetation plots were entered into a database created with TURBOVEG software (Hennekens, Schaminée, 2001) version 2.142. Materials were processed using Modified TWINSPAN (Roleček et al., 2009) (for separation of large dendrites) and PCORD (McCune, Mefford, 2006) (for receiving small phytocoenones) algorithms. The "pseudospecies" cut level is accepted at $0,5,15$ and $25 \%$. Heterogeneity of clusters was determined using the Whittaker's beta diversity index (Whittaker, 1978), the grouping of relevés in small phytocoenones was conducted with the Sørensen coefficient (Sørensen, 1948) at a "flexible beta" -0.25. The concept of fidelity is adopted in the establishment of diagnostic species of syntaxa (Chytrý et al., 2002). The threshold values for the corresponding coefficient are taken at the level of 0.25 . For highly diagnostic species, the phi coefficient exceeds 0.5. Statistical significance of the fidelity prior to equalization groups of relevés was calculated using the Fisher's exact test $(\mathrm{P}<0,001)$ (Chytrý et al. 2002). In the synoptic table (Table E1), diagnostic species are marked in light gray, highly diagnostic dark gray. The synoptic table is presented in a shortened form, without species observed rarely. It also does not include basal communities. The latter were determined by the method of Kopecký and Hejný (1974), in cases when the identification of vegetation plots to the level of association was impossible due to high heterogeneity of the taxonomic composition of phytocoenons that included species from syntaxa of different hierarchical levels. Basal communities were distinguished mainly by dominant species. Analysis of similarity of floristic composition was performed using the Jaccard similarity coefficient (Shmidt, 1980).
The syntaxonomic structure and content of the Stellarietea mediae class are accepted according to the latest overview of the vegetation of Ukraine (Dubyna et al., 2019).

The DCA-ordination method (Hill, Gauch, 1980) was used to identify the peculiarities of ecological differentiation of phytocoenoses. A basic statistical analysis (STATISTICA 10.0) was used, also applying ecological scales of Didukh (2011), for determining the ecological optimums of plant communities in relation to the leading ecological factors.

The nomenclature of taxa is given mainly according to the checklist of vascular plants of Ukraine (Mosyakin, Fedoronchuk, 1999), with some updates. The names of syntaxa are given in conformity with the rules and recommendations of the current edition of the International Code of Phytosociological Nomenclature $(I C P N)$ (Weber et al., 2000).

\section{Results and discussion}

The Stellarietea mediae class unites annual segetal and ruderal plant communities that are initial ones in the processes of overgrowing of newly formed anthropogenic ecotopes and are the first stages of vegetation restoration subjected to disturbance.

The syntaxonomic structure and circumscription of the class are quite debatable, especially after publication of the European Vegetation Checklist, where annual segetal and ruderal vegetation is distributed among four higher units of classification (Mucina et al., 2016). Thus, the authors proposed to include annual weed (segetal) vegetation of arable crops, gardens and vineyards of the cool-temperate and boreal zones of Eurasia in Papaveretea rhoeadis S. Brullo et al. 2001; zoo-anthropogenic and modern anthropogenic vegetation of animal shelters and disturbed ruderal sites of cool- and cold-temperate regions of Eurasia were placed in Sisymbrietea Gutte et Hilbig 1975; while winter-annual weed (segetal) and ruderal vegetation of man-made habitats of the Mediterranean, the mild-winter Atlantic seaboards and Macaronesia were treated in Chenopodietea Br.-Bl. in Br.- Bl. et al. 1952. In addition, a new class was distinguished, Digitario sanguinalis-Eragrostietea minoris Mucina, Lososová et Šilc in Mucina et al. 2016, which unites thermophilous grass-rich anthropogenic vegetation rich in summer-annual $\mathrm{C}_{4}$ species of the southern nemoral, mediterranean-type, steppe and semi-desert zones of Europe (Mucina et al., 2016). Some phytosociologists 
support such syntaxonomic differentiation of segetalruderal annual vegetation (Arepieva, 2017, 2019; Küzmič et al., 2018; Nazarov et al., 2019; Bulokhov et al., 2019), while other scientists continue to consider these plant communities within one widely circumscribed class Stellarietea mediae (Golovanov, Abramova, 2018; Dubyna et al., 2019; Chytrý et al., 2021). It is obvious that the typological and botanical-geographical differentiation of syntaxa proposed by L. Mucina and co-authors (Mucina et al., 2016) is open to discussion and needs further development because many questions remain unanswered, in particular, those related to differentiation of segetal and ruderal vegetation, the hierarchical position of classification units of middle ranks, their territorial distribution, etc. All these and other questions should be solved through large-scale comparative analyzes using big data sets of pan-European representativeness, as it has been done for other types of plant communities. These analyzes will either confirm the developed syntaxonomic constructions or, conversely, prompt concrete proposals to the Nomenclature Commission for rejecting proposed hierarchical systems, not only at the level of alliances or orders (Landucci et al., 2020) but also whole classes (Marceno et al., 2018). The authors follow a broad concept of the Stellarietea mediae class and consider that all phytocoenoses included in its structure develop only in conditions of permanent disturbance of vegetation or soil cover and are biomorphologically and ecologically similar. Although, a characteristic common feature of them is their differentiation into segetal and ruderal vegetation, while species composition of these coenoses is very similar. All differences are caused by various types, intensity, and nature of anthropogenic pressure, as well as environmental conditions, which is quite well reflected at the level of separate orders and alliances.

In the city of Kyiv, the Stellarietea mediae class is represented by 24 associations and 3 basal communities that belong to 8 alliances and 4 orders. They constitute $28 \%$ of the known syntaxonomic diversity of this class within the territory of Ukraine (Dubyna et al., 2019). Phytocoenoses of Stellarietea mediae are widespread throughout the city and are typical for waste places, outskirts of industrial enterprises and areas, nutrientrich soils in residential areas, railway embankments and highway roadsides, as well as for lawns and flower-beds. Plant communities of the class also occupy territories around construction sites that have increased significantly in area in recent years due to the active development of Kyiv. Phytocoenoses of Stellarietea mediae appear during the first stages of restorative successions in the territories of regular anthropogenic impact. In ecologicalcoenotic series, the vegetation of this class is replaced and succeeded by plant communities of Artemisietea vulgaris in dry habitats or Galio-Urticetea in conditions of higher soil humidity. In the territory of Kyiv, syndynamic processes have their own peculiarities and are characterized by a relatively stable phase of annual herbs, due to the predominance of ecotopes with sandy soils on which the change of succession stages is slower.

\section{Classification scheme of the Stellarietea mediae class in Kyiv:}

STELLARIETEA MEDIAE TX. ET AL. IN TX. 1950

Atriplici-Chenopodietalia albi (Tx. 1937) Nordhagen 1940

Panico-Setarion Sissingh in Westhoff et al. 1946

1. Amarantho retroflexi-Setarietum glaucae V. Solomakha et al. in V. Solomakha 1987

2. Echinochloo-Setarietum pumilae Felföldy 1942 corr. Mucina in Mucina et al. 1993 var. Ambrosia artemisifolia var. Taraxacum officinale

3. Setario viridis-Erigeronetum canadensis Šomšák 1976

4. Digitarietum ischaemii Tx. et Preising (1942) 1950

5. BC Setaria pumila

Polygono-Chenopodion Koch 1926

6. Ambrosio artemisiifoliae-Chenopodietum albi Marjushkina et V. Solomakha 1985

Eragrostietalia J.Tx. ex Poli 1966

Eragrostion Tx. in Oberd. 1954

7. Cynodontetum dactyli Gams 1927

8. Digitario sanguinalis-Eragrostietum minoris Tx. ex Rochow 1951

9. Eragrostio-Amaranthetum albi Morariu 1943

10. Portulacetum oleracei Felföldy 1942 var. Setaria viridis var. Berteroa incana var. Tribulus terrestris

Salsolion ruthenicae Philippi ex Oberd. 1983

11. Salsoletum ruthenicae Philippi 1971

12. BC Cenchrus longispinus

Papaveretalia rhoeadis Hüppe \& Hofmeister ex Theurillat et al. 1995

Chenopodio albi-Descurainion sophiae V. Solomakha et al. in V. Solomakha 1988 
13. Fallopio convolvuli-Chenopodietum albi V. Solomakha 1990

Sisymbrietalia sophiae J.Tx. ex Görs 1966

Atriplicion Passarge 1978

14. Atriplicetum hastatae Poli et J.Tx. 1960

15. Atriplicetum nitentis Slavnić 1951

16. Atriplicetum tataricae (Morariu 1943) Ubrizsy 1949

17. Chenopodietum stricti (Oberd. 1957) Passarge 1964

18. Kochietum densiflorae Gutte et Klotz 1985

19. Ambrosietum artemisiifoliae Viţălariu 1973

20. BC Atriplex patula

Hordeion murini Br.-Bl. in Br.-Bl. et al. 1936

21. .Brometum tectorum Bojko 1934 var. Diplotaxis tenuifolia

var. Polygonum aviculare

22. Hordeetum murini Libbert 1932

Malvion neglectae (Gutte 1972) Hejný 1978

23. Hyoscyamo nigri-Malvetum neglectae Aichinger 1933

Sisymbrion officinalis Tx. et al. ex von Rochow 1951

24. Erigeronto-Lactucetum serriolae Lohmeyer in Oberd. 1957

25. Ivaetum xanthiifoliae Fijałkowski 1967

26. Lactuco serriolae-Diplotaxietum tenuifoliae (Oberd. 1957) Mucina 1978

27. Sisymbrietum loeselii Gutte 1972

In Kyiv City, the Stellarietea mediae class includes such orders as: Atriplici-Chenopodietalia albi, Eragrostietalia, Papaveretalia rhoeadis, and Sisymbrietalia sophiae.

The order Atriplici-Chenopodietalia albi combines plant communities of ruderal habitats and plantations of ornamental plants on soils scarce in water and poor in mineral nutrients. It is diagnosed by the presence of following species: Amaranthus retroflexus L., Chenopodium album L. (sensu lato), Echinochloa crusgalli (L.) P.Beauv., Setaria pumila (Poir.) Roem. \& Schult. (S. glauca auct.), S. viridis (L.) P.Beauv. In the territory of Kyiv, this order is represented by two alliances, Panico-Setarion and Polygono-Chenopodion.

The alliance Panico-Setarion includes summer and late-summer weed vegetation of cereal crops occurring in anthropogenic dry and well-lit habitats with sandy and loamy soils. Its diagnostic species are: Amaranthus retroflexus, Convolvulus arvensis L., Echinochloa crusgalli, Galinsoga parviflora Cav., Setaria pumila, and $S$. viridis. In the territory of Kyiv, the alliance has three associations and one basal community.
Association Amarantho retroflexi-Setarietum glaucae Solomakha et al. in Solomakha 1987

D.s.: Amaranthus retroflexus, Setaria viridis.

Phytocoenoses of this association are sporadically distributed within Kyiv, mainly in the Sviatoshynskyi, Holosiivskyi and Darnytskyi districts, on sandy soils along communication routes, near garbage landfills and construction sites. Vegetation plots are characterized mostly by single-layer stands up to $150 \mathrm{~cm}$ high; their total cover varies from $30-40 \%$ (in habitats that are overgrown) to $60-80 \%$ (in the areas undergoing permanent human disturbance). They are usually formed by Amaranthus retroflexus, Chenopodium album, Setaria viridis, Conyza canadensis (L.) Cronq. (Erigeron canadensis L.), Ballota nigra L., and Elytrigia repens (Elymus repens (L.) Gould). Such species as Taraxacum officinale Wigg. (sensu lato), Polygonum aviculare L. and Convolvulus arvensis are also common. The coenoflora of this association is formed by at least 16 species, in some stands their number varies from 2 to 9 . Comparison of the floristic composition of this association with coenoses found in other urban agglomerations (Osypenko, 1996; Tokaryuk, 2019) (Table 1) generally showed significant similarities, mainly at the level of high-constancy species. Coenotaxonomic specificity is due to the high proportion of nitrophilic annual and perennial herbs in the phytocoenoses of Kyiv, as well as the low overall number of species in plant communities.

\section{Association Echinochloo-Setarietum pumilae Felföldy 1942 corr. Mucina in Mucina et al. 1993}

D.s.: Echinochloa crusgalli, Setaria viridis.

These plant communities are distributed sporadically in the city and have been detected in the Sviatoshynskyi, Desnianskyi and Holosiivskyi districts. Coenoses contain two or three sublayer, are characterized by a total cover of $60-100 \%$, and can be up to $120-150$ $\mathrm{cm}$ tall. It is dominated by Echinochloa crusgalli and Setaria viridis, less often by Chenopodium album. The number of species in the separate relevés varies from 7-9 to 16 , their total number is 34 . There are two variants within the association that differ ecotopically and in the composition of differential species. Phytocoenoses of Echinochloo-Setarietum pumilae var. Ambrosia artemisiifolia are common on sites with light, nutrientrich soils occurring in the vicinity of apartment buildings and private houses. Species of annual or biennial ruderal plants (Echium vulgare L., Daucus carota L., Lamium purpureum L.) have a significant role in the coenoflora of this variant. Stands of Echinochloo-Setarietum pumilae var. Taraxacum officinale grow on lighted, dry lawns, 
Table 1. Values of Jaccard similarity coefficients for associations of the class Stellarietea mediae in the territory of Kyiv compared with other cities and regions of Ukraine

\begin{tabular}{|c|c|c|c|c|c|c|c|}
\hline \multirow{2}{*}{ Associations } & \multicolumn{7}{|c|}{ Territories } \\
\hline & $\mathrm{KR}^{*}$ & Chk & NBS & $\mathrm{K}$ & $\mathrm{R}$ & $\mathrm{L}$ & Chn \\
\hline Amarantho retroflexi-Setarietum glaucae & - & 0.1 & - & 0.15 & - & - & 0.21 \\
\hline Echinochloo-Setarietum pumilae & - & 0.25 & - & - & - & - & 0.23 \\
\hline Setario viridis-Erigeronetum canadensis & 0.21 & - & - & - & - & - & - \\
\hline Digitarietum ischaemi & - & - & - & - & 0.16 & - & - \\
\hline Ambrosio artemisiifoliae-Chenopodietum albi & 0.25 & - & - & - & - & - & - \\
\hline Cynodontetum dactyli & - & - & 0.06 & 0.14 & - & - & - \\
\hline Digitario sanguinalis-Eragrostietum minoris & - & 0.19 & - & - & - & - & - \\
\hline Eragrostio-Amaranthetum albi & - & 0.18 & 0.2 & - & - & - & - \\
\hline Portulacetum oleracei & 0.24 & 0.2 & - & - & - & - & - \\
\hline Salsoletum ruthenicae & - & 0.15 & - & - & - & - & - \\
\hline Atriplicetum hastatae & - & - & 0.07 & 0.1 & - & - & - \\
\hline Atriplicetum tataricae & 0.22 & 0.1 & 0.1 & - & - & - & - \\
\hline Chenopodietum stricti & - & 0.13 & - & - & 0.24 & 0.21 & - \\
\hline Kochietum densiflorae & 0.17 & - & - & - & - & - & - \\
\hline Brometum tectorum & 0.29 & 0.12 & - & 0.03 & - & - & - \\
\hline Hordeetum murini & 0.26 & - & 0.12 & 0.1 & - & - & 0.16 \\
\hline Hyoscyamo nigri-Malvetum neglectae & - & 0.23 & - & - & 0.24 & - & - \\
\hline Erigeronto-Lactucetum serriolae & 0.28 & - & 0.09 & - & - & - & - \\
\hline Ivaetum xanthiifoliae & 0.13 & 0.16 & 0.13 & 0.21 & 0.08 & 0.09 & - \\
\hline Sisymbrietum loeselii & - & 0.19 & 0.15 & - & - & 0.15 & - \\
\hline
\end{tabular}

*KR - Kryvyi Rih; Chk - Cherkasy; NBS - Northern Black Sea Region; K - Kuyalnik Estuary; R - Roztochya; L - Lviv; Chn - Chernivtsi.

along sidewalks or roads with dense soils. As the plant communities are affected by trampling and periodic mowing, the floristic composition is characterized by a predominance of species from the diagnostic groups of Polygono-Poetea annuae (Polygonum aviculare, Plantago major L., Lolium perenne L.) and MolinioArrhenatheretea (Trifolium pratense L., Ranunculus polyanthemos L.). Comparison of plant communities of this association found in Kyiv with those in other cities and regions of Ukraine showed the greatest similarity to the coenoses described from the territory of Cherkasy (Osypenko, 1997) due to the similarity of ecotopes, in particular, their types and origin. Vegetation plots that are common in the Northern Black Sea region (Dubyna et al., 2004) and in Transcarpathia (Gamor, 1987) mostly occupy areas adjacent to the cultivated lands; thus, they are characterized by a more variable floristic composition due to numerous species of segetal and adjacent natural phytocoenoses.

\section{Association Setario viridis-Erigeronetum canadensis Šomšák 1976}

D.s.: Setaria viridis.

These plant communities are not found often in Kyiv. They occur mainly in the Holosiivskyi, Sviatoshynskyi and Darnytskyi districts, on ecotopes with sandy soils, sometimes with admixtures of gravel, which are not subject to constant anthropogenic impact. In particular, these areas comprise abandoned sites around buildings, habitats along or between railway tracks that are only sporadically used, etc. The coenoses' aspect is determined by Setaria viridis, which usually dominates together with Conyza canadensis or Chenopodium album. The stands are up to $80 \mathrm{~cm}$, have a total cover $40-80 \%$ and are composed of two sublayers. In the first sublayer, in addition to the dominants, the following species have high constancy: Medicago sativa L., Elytrigia repens, and Lolium perenne. In the second sublayer, such species as Berteroa incana (L.) DC., Potentilla argentea L., Grindelia squarrosa (Pursh) Dunal, Diplotaxis tenuifolia (L.) DC., and Fallopia convolvulus (L.) A.Löve, were noted most often. The total number of species in the coenoflora reaches 46 , in some relevés 9-14. In Ukraine, until now, such plant communities were mentioned only for Kryvyi Rig (Yeremenko, 2018), where the coenoflora is dominated by species of Panico-Setarion and Eragrostion. The phytocoenoses described from Kyiv have numerous and agglomerative character of their floristic composition. Their taxonomic structure is characterized by a combination of typical ruderal plants and representatives of the psammophytic 
floristic coenocomplex, in particular, those of the Koelerio-Corynephoretea canescentis class: Centaurea borysthenica Grun., Koeleria pyramidata (Lam.) P.Beauv. (K. cristata sensu Pers.), Artemisia campestris L. (sensu lato), Polygonum arenarium Waldst. \& Kit., Tragopogon borysthenicus Artemczuk.

Association Digitarietum ischaemii R. Tx. et Preising (1942) 1950

D.s.: Bromus squarrosus L., Crepis rhoeadifolia M. Bieb., Digitaria ischaemum (Schreb.) Muehl., Phalacroloma annuum (L.) Dumort. sensu lato (Erigeron annuus (L.) Desf.), Medicago sativa.

This association was first described by R.Tüxen and Preissing (Tüxen, 1950). Later, these plant communities were noted in the segetal vegetation of France (https:// www.e-veg.net/), Germany (Otte, 1984), Poland (AniokKwiatkowska, 1990) and Slovakia (Mochnacký, 1982), in the crop fields and in the adjacent habitats. Despite the fact that the discussed association was mentioned for the territory of Ukraine by Soroka (2008), the authors of the Stellarietea mediae class did not include Digitarietum ischaemii in the latest edition of the "Prodrome of the Vegetation of Ukraine" (Dubyna et al., 2019) due to the lack of representative information. European phytocoenologists mostly emphasized the low number of species in coenoses. Three variants of this association were described on the territory of the Masovian Landscape Park (Poland) (Ługowska, Skrajna, 2013): (1) a typical one, (2) with a group of hygrophytic species, and (3) with a high proportion of representatives of the ruderal vegetation classes. Plant communities found in Kyiv are most similar to the last variant. They were found near the Vydubychi railway station, on flat open uplands with chernozem sandy soils with admixtures of gravel or pebbles. Dense stands dominated by Digittaria ischaemum have a total cover of up to $80-90 \%$. In addition to diagnostic species of Panico-Setarion (Amaranthus retroflexus, Setaria pumila, S. viridis), representatives of the Sysimbrietalia sophiae order (Lactuca serriola L., Conyza canadensis, Phalacroloma annuum, Anisantha tectorum (L.) Nevski (Bromus tectorum L.), Bromus squarrosus) are often noted. There is a high proportion of diagnostic species of the Artemisietea vulgaris class (Melilotus alba Medik., Ballota nigra, Verbascum thapsus L., Elytrigia repens, Artemisia absinthium L.). In total, the coenoflora of the association includes 33 species (from 8 to 12 in some plots).

The basal community of Setaria pumila (usually listed in earlier literature as S. glauca auct.) has a sporadic distribution in the territory of Kyiv and occurs in narrow belts along transport routes, on flat areas with sandy and chernozem soils, mostly in the Holosiivskyi district. Stands are usually not dense (total cover 30-40\%), with a few species, and agglomerative. In addition to the dominant taxon (Setaria pumila), with the percentage cover up to $5 \%$, the coenoses are formed by some representatives of the Panico-Setarion alliance and other classes of anthropogenic vegetation. The most common species in the plant communities were Chenopodium album, Polygonum aviculare, Potentilla argentea, and Elytrigia repens.

The Polygono-Chenopodion alliance includes annual plant communities of nitrified habitats with chernozem sandy and loamy soils, which were identified based on the presence of Chenopodium album, Cirsium arvense (L.) Scop., Ambrosia artemisiifolia L., and Tripleurospermum inodorum (L.) Sch.Bip., and represented in the territory of Kyiv by one association.

Association Ambrosio artemisiifoliaeChenopodietum albi Marjushkina et Solomakha 1985

D.s.: Ambrosia artemisiifolia, Chenopodium album, Solidago canadensis L., Xanthium strumarium L. (sensu lato).

Phytocoenoses of this association are quite common in all administrative districts of the city and cover a wide range of ruderal habitats - garbage landfills, lawns, roadsides, sites within and near construction grounds, parking lots, cemeteries, areas of apartment buildings, etc. The stands are dense (total cover not less than $80 \%$, sometimes $100 \%$ ), their height reaches $120-150(180) \mathrm{cm}$. They are composed of two or three sublayers. In the first one, tall perennials from Artemisietea vulgaris (Elytrigia repens, Artemisia vulgaris L., Solidago canadensis) grow occasionally. In the second sublayer, diagnostic species of the association (Ambrosia artemisiifolia, Chenopodium album) mostly dominate. Plants from Stellarietea mediae (Cyclachaena xanthiifolia (Nutt.) Fresen. (= Iva xanthiifolia Nutt., Euphrosyne xanthiifolia (Nutt.) A.Gray), Phalacroloma annuum, Conyza canadensis, Setaria viridis, Sisymbrium loeselii L., Amaranthus retroflexus, Atriplex tatarica L., Echinochloa crusgalli) have high constancy. A sublayer with Polygonum aviculare, Plantago major, Eragrostis minor Host develops in the plots that are subjected to periodic trampling. The coenoflora of the association is formed by a total of 78 species. On average, some communities are composed of 12-13 taxa. When comparing the coenoses of the association from Kryvyi Rig (Yeremenko, 2018) with those described from Kyiv, their floristic similarity was determined at the level of 
the Jaccard coefficient of 0.25 . Besides, phytocoenoses in the investigated area are characterized by a much higher taxonomic diversity of communities and species complexity, due to the combination of both thermophilic annuals with Stellarietea mediae and mesophilic, often nitrophilic, representatives of Galio-Urticetea, Robinietea, Plataginetea majoris and MolinioArrhenatheretea.

The Eragrostietalia order combines thermophilic ruderal vegetation of low-growing annuals on dry sandy soils. The diagnostic species include Amaranthus albus L., Cynodon dactylon (L.) Pers., Digitaria sanguinalis (L.) Scop., Eragrostis minor, Portulaca oleracea L. (sensu lato), and Tribulus terrestris L. In the study area, the order was represented by two alliances Eragrostion and Salsolion ruthenicae.

The Eragrostion alliance consists of late-summer weed thermophilic plant communities occurring on sandy soils. Diagnostic species matched with those that are characteristic of the order. On the territory of Kyiv, four associations have been identified within the alliance.

\section{Association Cynodontetum dactyli Gams 1927}

D.s.: Cynodon dactylon, Phalacroloma annuum.

The information about plant communities of this association within Kyiv is mainly based on the data of Melezhik (Chokha, 2007). The author described them from the lawns of the city, on sandy substrates with low soil humidity and periodic trampling. Cynodon dactylon dominates in stands with a total cover of 100\%. Conyza canadensis, Elytrigia repens, Plantago lanceolata L., Taraxacum officinale, and Berteroa incana are characterized by high constancy. The total number of species in coenoses is 16 . In some relevés, $7-8$ species were recorded on average. The association on the territory of Ukraine was reported mainly from the southern regions, where the communities prefer open, warm ecotopes and are composed of typical thermophilic species. Comparisons with these communities showed high similarity only at the level of constant species. For other species, some differences were observed. In particular, the participation of mesoxerophytic species tolerant of trampling in Kyiv in contrast to eurytopic representatives of various florocomplexes (halophytic, hygrophytic, psammophytic) in the Kuyalnyk Estuary area (Dubyna et al., 2018) and in the Northern Black Sea region (Dubyna et al., 2004). The occurrence and spread of the association's coenoses within Kyiv indicate the intensification of xerophytization processes of the enviromental conditions in the city.

Український ботанічний журнал, 2021, 78(3)
Association Digitario sanguinalis-Eragrostietum minoris Tx. ex Rochow 1951

D.s.: Digitaria sanguinalis, Festuca ovina L. (sensu lato)

Phytocoenoses of this association within Kyiv are quite common, mainly in the Obolonskyi, Pecherskyi, and Holosiivskyi districts. They are observed in plain areas, along sidewalks, tram tracks, public transport stops, near railway stations with gravelly substrates or low-humus sandy soils. Plant communities consist of a few species. On average, there are 6-7 taxa in one relevé, with a total number of 47 in all coenoflora. Stands are dense (total cover $60-80 \%$ ), up to $60 \mathrm{~cm}$ in height, dominated by Eragrostis minor and Digitaria sanguinalis, sometimes by Elytrigia repens. Other species of the Eragrostion alliance (Medicago lupulina L., Portulaca oleracea, Amaranthus blitoides S. Watson), as well as representatives of the Panico-Setarion alliance (Setaria viridis, S. pumila, Chenopodium album) occur in high proportions. Polygonum aviculare, Plantago lanceolata, P. major are typical in trampling sites. In contrast to the territories of other cities, in particular Cherkasy (Osypenko, Shevchyk, 2001), where the significant role has representatives of genetically previous plant formations (psammophytic for example), coenotaxonomic specificity of investigated plant communities showed a significant representation of typical ruderal species, which indicates a higher level and intensity of anthropogenic transformations of ecotopes.

Association Eragrostio-Amaranthetum albi Morariu 1943

D.s.: Amaranthus albus, Echinochloa crusgalli, Erysimum cheiranthoides L., Lepidium ruderale L., Lolium perenne, Sonchus arvensis L.

The association unites heliophytic communities in post-demutation areas with different types of substrates. In the territory of Kyiv they were described from lawns in the Pecherskyi and Podilskyi districts. The total cover of coenoses varies from $30 \%$ on nutrient-poor sandy soils to $90 \%$ on chernozems. The height of the stands reaches $60-80 \mathrm{~cm}$ and they are composed of two or three sublayers. In the first one, Lolium perenne, Echinochloa crusgalli, Chenopodium album, Setaria pumila, Sonchus arvensis were noted with low cover. The second sublayer is dominated by Amaranthus albus, Eragrostis minor, Malva neglecta Wallr., Lepidium ruderale, Plantago major. A sublayer formed by Polygonum aviculare develops in the trampling areas. On average, some vegetation plots have 10-11 species, the coenoflora is formed by 36 taxa. The characteristic features of the association within Kyiv in comparison with other 
territories (Osypenko, 1999; Dubyna et al., 2004) are the high number of species in the coenoses and the prevalence of nitrophilous species in their ecological spectra.

Association Portulacetum oleracei Felföldy 1942

D.s.: Portulaca oleracea (sensu lato), Tribulus terrestris.

This association is quite common in Kyiv and is found in all administrative-territorial units. It occupies mostly sunny ecotopes with gray and chernozem soils, located along highways, sidewalks, railways, and fences. The total cover of coenoses varies from $30-40 \%$ to 80 $95 \%$. The coenoflora of this association is formed by 49 species. Some plant communities are composed of 7-11 taxa; among them, Chenopodium album, Oxybasis rubra (L.) Fuentes, Uotila \& Borsch (Chenopodium rubrum L.), Conyza canadensis, and Anisantha tectorum are constant species. Within the association, we distinguished three ecological variants. Phytocoenoses of Portulacetum oleracei var. Setaria viridis are common on periodically trampled dry plots with gray and dark gray sandy soils. These coenoses are characterized by their rich species composition and a combination of representatives mainly of the classes: Stellarietea mediae (Ambrosia artemisiifolia, Atriplex patula L., Amaranthus retroflexus, Eragrostis minor) and Polygono-Poetea annuae (Plantago lanceolata, Lolium perenne, Polygonum aviculare). Coenoses of Portulacetum oleracei var. Berteroa incana are characterized by dense (total cover $80-95 \%$ ) stands that occur on chernozems, sometimes with gravel and pebble fractions, near abandoned or infrequently used railway tracks. A comparatively lower level of anthropogenic pressure and its irregularity determine the taxonomic differentiation of plant communities according to the diagnostic group of Artemisietea vulgaris (Berteroa incana, Malva neglecta, Elytrigia repens, Convolvulus arvensis, Potentilla argentea). Phytocoenoses of Portulacetum oleracei var. Tribulus terrestris are the most xerophytic within the association. They are distributed on gravelly soils along the city railways. Tribulus terrestris, a Eurasian species that until recently was mostly observed in the vegetation of southern Ukraine, dominates in the communities with a cover of 15 to $30 \%$. In Kyiv, plant communities with this species occur on gravelly railway embankments, where the microclimate is very similar to more typical species' habitats, in particular, due to the high degree of insolation, low soil humidity, and high air temperature, as compared to surrounding areas. An important role in the northward migration of Tribulus terrestris may play global climate changes. Among more common species in stands there are also other typical xerophytes, such as Plantago arenaria and Salsola tragus L. Phytocoenoses of Portulacetum oleracei recorded in Kyiv are generally similar to those in other cities of Ukraine. The similarity with the coenoses of the association described from Kryvyi Rig (Yeremenko, 2018) is manifested in the number of thermophilic annual plant species, while in Cherkasy (Osypenko, 1996) - in the presence of nitrophilous mesoxerophytes.

The Salsolion ruthenicae combines ruderal plant communities of annuals on disturbed sandy-gravel devastated soils. This alliance is quite well distinguished by the presence of xerophytic species, in particular Salsola tragus (formerly often reported under the illegitimate name $S$. ruthenica Iljin) and Anisantha tectorum. In the territory of Kyiv, it is represented by one association and one basal community.

\section{Association Salsoletum ruthenicae Philippi 1971}

D.s.: Salsola tragus.

This association was first described for Ukraine by Osypenko and Shevchyk (2001) from Cherkasy. It was noted on devastated soils near newly constructed buildings in the city. These plant communities are distributed sporadically in the city. The total cover of coenoses reaches $90 \%$. The dominating species is Salsola tragus, sometimes with Chenopodium album (5-10\%) or Ambrosia artemisiifolia (to 5\%). The floristic composition of coenoses is formed by diagnostic species of Stellarietea mediae (Setaria viridis, Portulaca oleracea, Digitaria sanguinalis) that are undemanding to the water-mineral regime of soils.

The basal community Cenchrus longispinus was found near the Kyiv-Dniprovskyi railway platform, where it occupies railway hills with sandy soils, as well as open, well-sunlit lawns along highways near the Osokorky metro station. Stands are medium-dense, have a total cover of $40-60 \%$ and one sublayer up to $60 \mathrm{~cm}$ tall, in which, in addition to the dominant dangerous quarantine species Cenchrus longispinus (Hack.) Fernald, most common are species of the alliance Salsolion ruthenicae - Digitaria sanguinalis, Salsola tragus, Anisantha tectorum and Eragrostis minor. These phytocoenoses are distinguished by significant participation of typical psammophytic species, representatives of the Koelerio-Corynephoretea canescentis (Silene borysthenica (Grun.) Walters (Otites borysthenicus (Grun.) Klokov), Chondrilla juncea L. sensu lato, Oenothera bienis L. sensu lato) and Festucetea vaginatae classes (Festuca beckeri (Hack.) Trautv., Secale sylvestre Host, Centaurea borysthenica, Polygonum arenarium, Plantago arenaria).

Ukrainian Botanical Journal, 2021, 78(3) 
The Papaveretalia rhoeadis order includes segetal vegetation occurring on rich soils in the steppe and forest-steppe zones of Ukraine. Diagnostic species are: Capsella bursa-pastoris (L.) Medik., Cirsium arvense, Convolvulus arvensis, Conyza canadensis, Fallopia convolvulus, and Sonchus arvensis. In Kyiv, the order is represented by one alliance and one association. The Chenopodio albi-Descurainion sophiae alliance contains weed phytocoenoses, occurring mainly on chernozem soils.

\section{Association Fallopio convolvuli-Chenopodietum albi Solomakha 1990}

D.s.: Fallopia convolvulus, Linaria vulgaris Mill.

These plant communities are not very common in Kyiv and do not occupy large areas. They were found near the Vydubychi railway platform, on light chernozem soils. Stands are usually dense with a total cover up to $90 \%$, reaching a height of $70-80 \mathrm{~cm}$, and consist of two sublayers. The first sublayer is formed by such species as Chenopodium album, Oxybasis rubra, Setaria viridis, Amaranthus retroflexus, Conyza canadensis, Linaria vulgaris, Diplotaxis tenuifolia, and Phalacroloma annuum. The lower sublayer consists of Fallopia convolvulus, Portulaca oleracea, Convolvulus arvensis, and Polygonum arenarium. Phytocoenoses are floristically rich, with 13-14 species in each relevé. The total number of species in the coenoflora is 28 taxa.

The Sisymbrietalia sophiae order includes xerophytic plant communities of disturbed habitats with nutrient-rich soils. Diagnostic species are: Anisantha tectorum, Atriplex prostrata Boucher ex DC., A. tatarica, Diplotaxis muralis, D. tenuifolia, Cyclachaena xanthiifolia, Lactuca serriola, Malva neglecta, Sisymbrium loeselii, S. officinale, and Xanthium strumarium (sensu lato). In Kyiv, the order is characterized by a high level of syntaxonomic diversity and represented by four alliances - Atriplicion, Hordeion murini, Malvion neglectae and Sisymbrion officinalis.

The Atriplicion alliance includes xerophytic ruderal phytocoenoses of tall annual herbs, occurring on nitrified sandy soils. The group of diagnostic species includes: Artemisia vulgaris, Atriplex prostrata, A. tatarica, Chenopodium album, and Chenopodiastrum hybridum (L.) Fuentes, Uotila \& Borsch (Chenopodium hybridum L.). In Kyiv, 6 associations and one basal community of the alliance were described.

Association Atriplicetum hastatae Poli et J. Tx. 1960 D.s.: Atriplex prostrata, Portulaca oleracea.

Phytocoenoses of this association occupy areas around the apartment building grounds in the Sviatoshynskyi,
Darnytskyi, Desnianskyi districts with nitrified soils. Plant communities are characterized by a low species richness (5-6 species in the relevé with a total taxa number of 12), high density (total cover 60-70\%), and medium height $(60-70 \mathrm{~cm})$ of stands, dominated by Atriplex prostrata. Hordeum murinum L., Ambrosia artemisiifolia, Portulaca oleracea with a cover 5-10\% are often present. In Ukraine, coenoses of Atriplicetum hastatae were previously mentioned only for coastal areas (Dubyna et al., 2004). Comparison of them did not show much similarity. Thus, in Kyiv the floristic composition of the association is formed mainly by species of the Atriplicion alliance, while in other territories, the phytocoenoses are more variable in their floristic composition due to representatives of different classes of both natural and synanthropic vegetation.

\section{Association Atriplicetum nitentis Slavnić 1951}

D.s.: Atriplex sagittata Borkh., Parthenocissus quinquefolia (L.) Planch. sensu lato.

Plant communities of this association are rarely noted within Kyiv. They are described from the "Zvirynets" area, occurring in disturbed habitats with loamy soils, adjacent to semi-natural nitrophilous coenoses of the Galio-Urticetea class. Stands of the association are dense (80-90\%), have 80-100 cm in height, and are composed of species (6-7 in one relevé) representing different classes of anthropogenic vegetation, in particular Robinietea, Stellarietea mediae, Artemisietea vulgaris and Galio-Urticetea. A dominating species is Atriplex sagittata with a cover of 50-60\%. Elytrigia repens (cover to $10-15 \%)$, Conyza canadensis (5-10\%), and Oxybasis rubra (up to 5\%) also play a significant role.

\section{Association Atriplicetum tataricae (Morariu 1943) Ubrizsy 1949}

D.s.: Atriplex tatarica.

Phytocoenoses within Kyiv are distributed on compacted soils with increased salinization along roadsides and sidewalks. They were described from the Holosiivskyi and Obolonskyi districts. The total cover of communities is 55-70 (100)\%. Atriplex tatarica dominates in the stands, which reach a height of $60 \mathrm{~cm}$ and consist of two sublayers. In the first sublayer, Portulaca oleracea, Hordeum murinum, Anisantha tectorum, Grindelia squarrosa, and Conyza canadensis are characterized by high constancy. Second sublayer, with a cover $5-15 \%$, is formed by Polygonum aviculare. When comparing the floristic composition of the association from different regions of Ukraine, the coenoses described from Kyiv have the greatest similarity to those occurring 
in Kryvyi Rig (Yeremenko, 2018), due to the similarity of the group of diagnostic and constant species, as well as a high proportion of thermophilic annuals resulting from thermo- and light regimes of communities' habitats.

Association Chenopodietum stricti (Oberd. 1957)

\section{Passarge 1964}

D.s.: Chenopodium album, Glechoma hederacea L.

Phytocoenoses of this association are one of the most common in the ruderal habitats of Kyiv. They are found along roadsides and sidewalks, in lawns, abandoned children and sports grounds, and near buildings and industrial sites of the city. Coenoses are confined to the disturbed substrates with increased content of nitrogenous compounds. Stands are usually dense, with a total cover up to $80-100 \%$ and height of $120-150 \mathrm{~cm}$, composed of three sublayers. The first one is formed by tall nitrophylic herbs, such as: Chenopodium album, Artemisia vulgaris, Lactuca serriola, and Amaranthus retroflexus. For the second sublayer, typical are Ambrosia artemisiifolia, Conyza canadensis, Setaria pumila, Anisantha tectorum, Digitaria sanguinalis, and Hordeum murinum. The lower sublayer forms Polygonum aviculare, together with other low-growing anthropophytes, such as Convolvulus arvensis, Glechoma hederacea, Plantago major, and Eragrostis minor. A total of 83 species were recorded in the plant communities, of which 6-8 form separate coenoses. At the level of diagnostic and constant species, phytocoenoses in Kyiv are quite similar to those described from other cities of Ukraine (Kucheryavyi et al., 1991; Osypenko, Shevchyk, 2001; Soroka, 2008). Coenotaxonomic specificity consists in a relatively high participation of species from the Artemisietea vulgaris class in the structure of coenoses and a high dominant role of plants from the group of transformers, in particular, Ambrosia artemisiifolia, Conyza canadensis, and Grindelia squarrosa.

\section{Association Kochietum densiflorae Gutte et Klotz 1985}

D.s.: Kochia scoparia (L.) Schrad. (Bassia scoparia (L.) A.J.Scott)

These plant communities within Kyiv were described from the Dniprovskyi and Pecherskyi districts. They prefer waste dumps on building grounds and roadsides with degraded gray and chernozem soils. Stands are not dense (total cover 30-40\%) and contain few species (on average 3-5 species per relevé, with a total number of 24 in all coenoflora). Herb layer reaches height up to 80 $\mathrm{cm}$ and consists of two sublayers. The first one is formed by Kochia scoparia, Anisantha tectorum (5-10\%) and other representatives of the Stellarietea mediae class (Lactuca serriola, Conyza canadensis, Ambrosia artemisiifolia, Chenopodium album, Sisymbrium loeselii, Atriplex sagittata, and Setaria viridis). Eragrostis minor, Diplotaxis tenuifolia, and Plantago major are often noted in the lower sublayer. Comparisons of the Kyiv and Kryvyi Rih association's communities (Yeremenko, 2018; Smetana, 2002) generally showed the similarity of diagnostic and constant species. The differences are caused by the high proportion of psammophytic species (for example, Artemisia campestris, Centaurea borysthenica, and Medicago sativa) in the study area.

Association Ambrosietum artemisiifoliae Viţălariu 1973

D.s.: Ambrosia artemisiifolia, Oenothera biennis (sensu lato).

This association was first described by Viţălariu (1973) along the railways of Moldova. In Ukraine, coenoses where Ambrosia artemisiifolia plays a significant or even dominant role were classified either as derivate communities hierarchically related to different alliances, orders or classes of anthropogenic vegetation (Dubyna et al., 2018), or referred to several associations, which in the latest vegetation survey of Ukraine were either recognized as valid or sometimes reduced to synonyms (Dubyna et al., 2019). In general, the classification of phytocoenoses with invasive plants is a quite difficult task (Abramova, 2012). This is due to the fact that such species are highly dominant and have wide ecologicalcoenotic amplitudes, so they can form aspects in different classes of anthropogenic vegetation. Researchers often use rankless units, such as derivate or basal communities, to identify such coenoses. Associations with invasive species are recognized only when they are dominated by representatives of one syntaxonomic unit of the highest hierarchical level.

To establish the syntaxonomic position of phytocoenoses with Ambrosia artemisiifolia, we compared the qualitative and quantitative indicators of floristic composition of all associations described or registered from Ukraine where this species is diagnostic, and built a dendrogram (Fig. 1). This confirmed our decision to assign the status of association to the coenoses with $A$. artemisiifolia occurring in Kyiv.

Within Kyiv, Ambrosietum artemisiifoliae communities were found in all administrative-territorial districts of the city, mainly along the railway tracks, highways and sidewalks, on the slopes of large transport interchanges, lawns, etc. They often prefer landfills and construction waste grounds, abandoned territories and areas with 


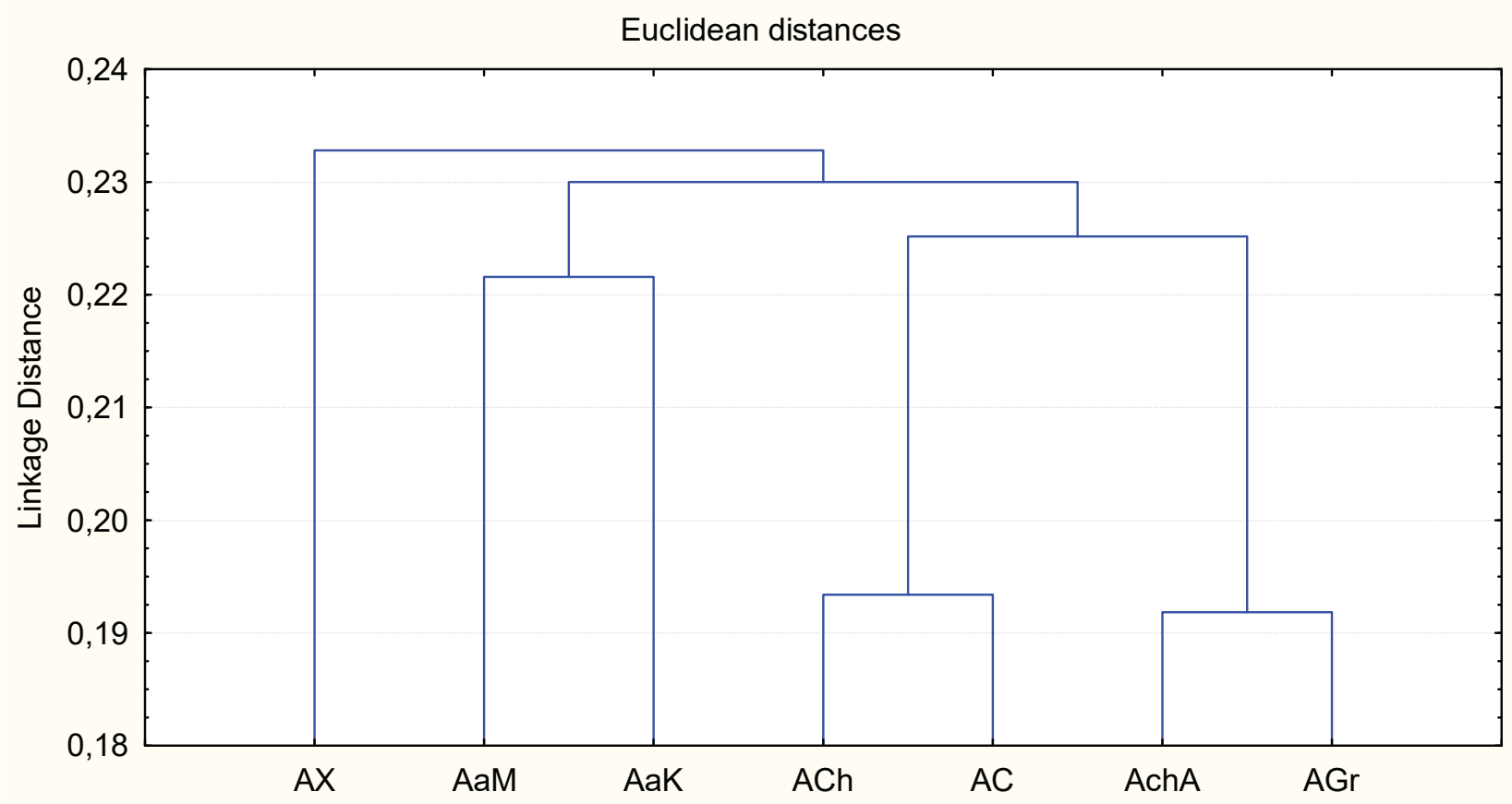

Fig. 1. Dendrogram of similarity of floristic composition of plant communities with Ambrosia artemisiifolia participation.

AX - Ambrosio artemisiifoliae-Xanthietum strumariae Kostylev in V. Solomakha et al. 1992; AaM - Ambrosietum artemisiifoliae Viţălariu 1973 (plant communities described from Moldova); AaK - Ambrosietum artemisiifoliae Viţălariu 1973 (plant communities described from Kyiv); ACh - Ambrosio artemisiifoliae-Chenopodietum albi Marjushkina et V. Solomakha 1985; AC - Ambrosio artemisiifoliae-Cirsietum setosi Marjushkina et V. Solomakha 1985; AchA - Achilleo-Ambrosietum artemisiifoliae Smetana 2002; AGr - Ambrosio artemisiifoliae-Grindelietum squarrosae Smetana 2002

agglomerative soils. The aspect of these coenoses is determined by the dominance of the diagnostic species Ambrosia artemisiifolia, the cover of which sometimes reaches $80-90 \%$. The floristic composition is dominated by species from Stellarietea mediae, of which the most common are Anisantha tectorum, Setaria pumila, Conyza canadensis, Phalacroloma annuum, and Lactuca serriola. In some habitats, a significant role is played by representatives of the classes Artemisietea vulgaris (Elytrigia repens, Artemisia vulgaris, A. absinthium, Berteroa incana, Convolvulus arvensis, Daucus carota) and Polygono-Poetea annuae (Polygonum aviculare, Lolium perenne). The stands are composed of two or three (in trampling areas) sublayers. A total of 75 species were noted in the communities, on average $8-10$ of them were recorded in separate relevés.

The basal community of Atriplex patula is quite common in Kyiv on abandoned roadside areas with disturbed nitrified soils. It is characterized by a few species stands with a total cover of $60-80 \%$ and a height of $80 \mathrm{~cm}$. This community is dominated by Atriplex patula, with the participation of Elytrigia repens, Amaranthus retroflexus, Oxybasis rubra, Chenopodiastrum hybridum, Conyza canadensis, and Sonchus oleraceus.

The Hordeion murini alliance includes ruderal plant communities in mechanically disturbed anthropogenic habitats with the highest deficit of soil humidity. The group of diagnostic species is formed by typical xerophytes - Anisantha sterilis (L.) Nevski (Bromus sterilis L.), A. tectorum, Bromus squarrosus, Hordeum murinum, and Secale sylvestre. In Kyiv, the alliance is represented by two associations.

\section{Association Brometum tectorum Bojko 1934}

D.s.: Anisantha tectorum.

Plant communities of this association are quite common in Kyiv and occupy different types of habitats. They form open, well sunlit ecotopes with loose sandy, loamy and gravelly substrates along railways and tramways, on sides of highways, near residential buildings, and on abandoned play and sport grounds. The total cover of coenoses ranges from $35-40 \%$ to $80-90 \%$. The stands reach a height of $60-80 \mathrm{~cm}$. They 
are dominated by Anisantha tectorum. Such species as Lactuca serriola, Conyza canadensis, Phalacroloma annuum, Crepis tectorum L., Amaranthus retroflexus, Convolvulus arvensis and Taraxacum officinale have high constancy there. In total, 75 species were found in the phytocoenoses, on average 6-7 per relevé. Depending on the type of anthropogenic pressure and its intensity, there are two variants distinguished within the association. Phytocoenoses of Brometum tectorum var. Diplotaxis tenuifolia occur mainly along transport routes. The stands are medium-dense (the total cover does not exceed 45-60\%), composed of two sublayers. The variant is characterized by the predominance of representatives of the Stellarietea mediae class (Diplotaxis tenuifolia, Setaria pumila, Eragrostis minor, Ambrosia artemisiifolia, Fallopia convolvulus, Salsola tragus). Some species of Artemisietea vulgaris, in particular, Elytrigia repens, Ballota nigra, and Artemisia absinthium, are also common. Plant communities of Brometum tectorum var. Polygonum aviculare are typical for areas with intensive trampling (along sidewalks, spontaneous paths, in park areas). The stands have a total cover of $70-80 \%$ and are differentiated into three sublayers. In addition to Anisantha tectorum and constant species of the association, plants with high tolerance to trampling (Polygonum aviculare, Plantago lanceolata, P. major, Atriplex tatarica) occur in a high proportion in the coenoflora of this variant. Qualitative and quantitative comparisons of the association's phytocoenoses from different regions and cities of Ukraine showed that plant communities in Kyiv are most similar to those described from Kryvyi Rig (Yeremenko, 2018). The main differences are related to various conditions of soil humidity and are reflected in the proportion of xerophytic and mesophytic species in the coenofloras. In addition, the floristic structure of phytocoenoses in the study area is complex and composed not only of species of different classes of anthropogenic vegetation, but also of constant species from Molinio-Arrhenatheretea, KoelerioCorynephoretea canescentis, and Trifolio-Geranietea sanguinei.

\section{Association Hordeetum murini Libbert 1932}

D.s.: Hordeum murinum, Taraxacum serotinum (Waldst. \& Kit.) Poir.

Plant communities of this association in the territory of Kyiv are typical for all administrative-territorial districts. Phytocoenoses often occupy roadsides and other marginal habitats with dry compact soils. The total cover of coenoses is $70-80 \%$. Hordeum murinum dominates in stands that usually do not exceed $50-60 \mathrm{~cm}$ in height.
There are also some representatives of Stellarietea mediae, such as: Lactuca serriola, Chenopodium album, Conyza canadensis, Amaranthus retroflexus, Ambrosia artemisiifolia, Capsella bursa-pastoris, and Atriplex tatarica, with a percentage of $5-15 \%$ and high constancy. The proximity of the phytocoenoses to the areas of intensive trampling determines the high representation of the Polygono-Poetea annuae diagnostic group, with such species as Polygonum aviculare, Taraxacum officinale, T. serotinum, Lolium perenne, Plantago major, P. lanceolata, and Poa annua L. In the areas of only occasional anthropogenic disturbance, hemicryptophytes from Artemisietea vulgaris (Elytrigia repens, Artemisia vulgaris, Convolvulus arvensis, Ballota nigra, Glechoma hederacea, Urtica dioica L.) are often observed. The coenoflora of the association consists of 44 species, usually 5-7 per one relevé. Compared to other cities and regions of Ukraine (Yeremenko, 2018; Dubyna et al., 2004, 2018; Tokaryuk, 2019), in Kyiv the association's communities do not have a diverse floristic spectra of coenoses and are characterized by the predominance of species of synanthropic vegetation classes from the xerophytic ecological group.

The Malvion neglectae alliance, which combines coenoses of marginal localities occurring on moderately humid and nutrient-rich soils, is represented in Kyiv by only one association and is determined mostly based on the presence of Malva neglecta, Plantago major, and Polygonum aviculare.

\section{Association Hyoscyamo nigri-Malvetum neglectae Aichinger 1933}

D.s.: Lolium perenne, Malva neglecta, Tripleurospermum inodorum, Poa annua, Sisymbrium loeselii, Trifolium repens $\mathrm{L}$.

Within Kyiv, these plant communities occur sporadically on compacted nitrified soils and were found along sidewalks and near paths between the private houses of the Sviatoshynskyi district and near the Slavutych metro station. The coenoses of the association are represented by scioheliophytic stands of low-growing therophytes with a total cover of 70-90\%, differentiated into one or two sublayers. The dominating species is Malva neglecta, while such species as Lolium perenne, Chenopodium album, Tripleurospermum inodorum, Sisymbrium loeselii, Poa annua, Plantago major, and Trifolium repens also play a significant role in stands. The coenoflora is formed in total by 19 species, with 6-7 species per relevé. Comparisons of association's communities in the study area with similar ones within Ukraine (Soroka, 2008; Osypenko, 1997) in general 
demonstrated their high similarity at the level of the groups of diagnostic and constant species. In Kyiv, the coenoses are characterized by a high dominance of the edificator species (Malva neglecta), a low number of taxa, and a significant quantitative and qualitative presence of representatives of the Polygono-Coronopodion alliance.

The Sisymbrion officinalis includes ruderal plant communities occurring on little-disturbed nitrified substrates. Its diagnostic species are: Atriplex tatarica, Chenopodium album, Sisymbrium loeselii, $S$. officinale (L.) Scop., and Xanthium strumarium (sensu lato). The alliance is represented in Kyiv by four associations.

\section{Association Erigeronto-Lactucetum serriolae Lohmeyer in Oberd. 1957}

D.s.: Convolvulus arvensis, Conyza canadensis, Lactuca serriola, Setaria pumila, Tripleurospermum inodorum.

Phytocoenoses are noted sporadically in the territory of Kyiv, most often in the Holosiivskyi, Darnytskyi, and Pecherskyi districts and in the Raiduzhnyi residential area. Plant communities grow on roadsides, in dumping sites, near railway hills, as well as on lawns in conditions of insufficient soil humidity. They prefer mainly loamy, sandy, and gravelly substrates with a low concentration of water and mineral nutrients. The total cover of stands varies from 40 to $85 \%$. They are formed mainly by Lactuca serriola and Conyza canadensis. The phytocoenoses are composed of two or three sublayers. The first one, which can reach a height of 120-150 $\mathrm{cm}$, comprises Lactuca serriola, Chenopodium album, Arctium lappa L., Artemisia absinthium, and Verbascum thapsus. The second sublayer $(50-60 \mathrm{~cm}$ in height) is dominated by Conyza canadensis, often Anisantha tectorum, Setaria pumila, Elytrigia repens, Ambrosia artemisiifolia, Diplotaxis tenuifolia, Ballota nigra, Amaranthus retroflexus, and Capsella bursa-pastoris. The third layer is composed of low-growing annual and perennial herbs. Among them, Polygonum aviculare, Hordeum murinum, Portulaca oleracea, Convolvulus arvensis, and Eragrostis minor are most often recorded. The coenoflora of the association consists of a total of 48 species, while some relevés have on average 8-9 species. The plant communities of ErigerontoLactucetum serriolae are most similar to those described from in Kryvyi Rig (Yeremenko, 2018), especially in terms of diagnostic and constant species. Characteristic differences found in the Kyiv coenoses include a high representation of psammophytic florocoenoelements and relatively low participation of low-growing annuals and perennials from the diagnostic group of PolygonoPoetea annuae.
Association Ivaetum xanthiifoliae Fijałkowski 1967

D.s.: Artemisia vulgaris, Cyclachaena xanthiifolia (Iva xanthiifolia).

These phytocoenoses are sporadically observed on loamy and sandy soils, mostly in waste places or along roads, mainly in the Sviatoshynskyi and Desnianskyi districts of Kyiv. The plant communities' stands are dense, with a total cover up to $100 \%$, reach a height of $150 \mathrm{~cm}$, and are composed of two sublayers. The first one is dominated by Cyclachaena xanthiifolia, a significant role is also played by Chenopodium album (5-15\%) and Artemisia vulgaris (5-10\%). In the second sublayer, most common species are Ambrosia artemisiifolia, Elytrigia repens, Setaria viridis, and Bromus squarrosus. In total, the phytocoenoses of the association are formed by 19 species, of which from 7 to 13 are recorded in some vegetation plots. The coenoses in Kyiv are most similar to those which were found in Cherkasy (Osypenko, Shevchyk, 2001), in the localities of Poltava region (Gomlya, 2005) (at the level of Jaccard similarity coefficient of 0.16), and in the Kuyalnyk Estuary area (Dubyna et al., 2018). First of all, the similarity occurs in a group of constant and dominant species, as well as affinity ones. The latter are dominated by xerophytic representatives of Stellarietea mediae. In other areas, the diagnostic groups of different rank syntaxa from the Artemisietea vulgaris class are more prominent.

\section{Association Lactuco serriolae-Diplotaxietum tenuifoliae (Oberd. 1957) Mucina 1978}

D.s.: Berteroa incana, Diplotaxis tenuifolia, Picris hieracioides, Potentilla argentea.

In Ukraine, plant communities of this association were earlier mentioned only for the Crimean Peninsula, where they were found in vineyards and among row crops on nutrient-rich substrates (Bagrikova, 2004). In Kyiv, these coenoses were found near the Sviatoshyn and KyivDemiivskyi railway stations on undisturbed chernozems with gravel fractions near the railway tracks on which irregular transportation is carried out. The total cover of plants varies from 40 to $90 \%$, the height reaches 120 $150 \mathrm{~cm}$. Stands are differentiated into two sublayers. The first one is dominated by Lactuca serriola, often with Elytrigia repens. The second dense sublayer is formed by Diplotaxis tenuifolia, Setaria viridis, S. pumila, and Ambrosia artemisiifolia. Due to the unstable anthropogenic impact, species of Artemisietea vulgaris, in particular from the ecological group of mesophytes, play a significant role in phytocoenoses of the association. Among them, Berteroa incana, Artemisia absinthium, Crepis rhoeadifolia, and Ballota nigra are most common. 


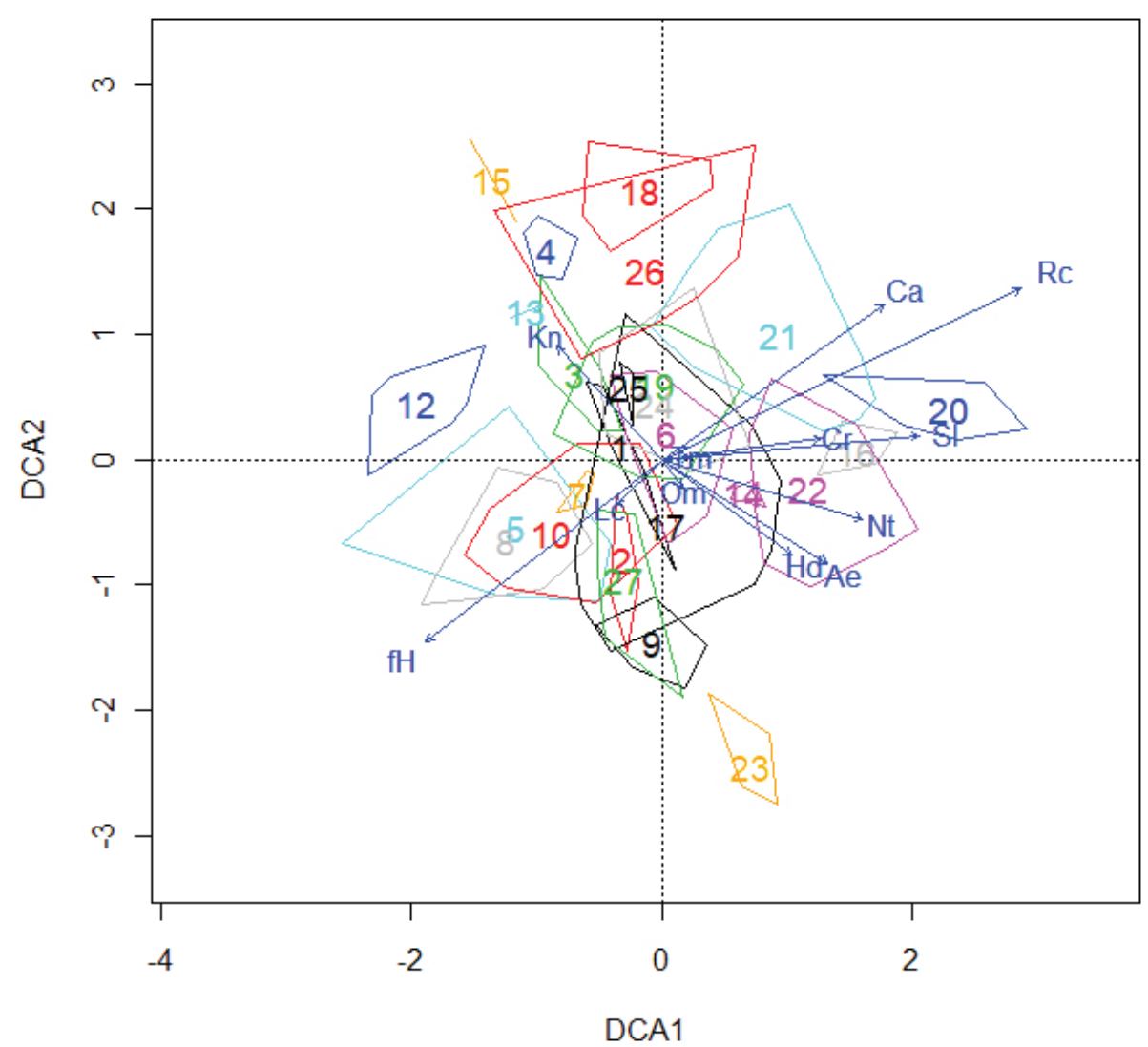

Fig. 2. Results of DCA-ordination of plant communities of the Stellarietea mediae class by ecological factors: Hd - soil humidity, $\mathrm{fH}$ - variability of damping, $\mathrm{Rc}$ - soil acidity, $\mathrm{Sl}$ - salt regime, $\mathrm{Ca}$ - carbonate content, $\mathrm{Nt}$ - nitrogen content, Ae - soil aeration, $\mathrm{Tm}$ - termoregime, $\mathrm{Om}$ - ombroregime, $\mathrm{Kn}$ - continentality of climate, $\mathrm{Cr}$ - cryoregime, Lc - light regime.

The numbers indicate syntaxa that correspond to those given in the classification scheme

Near sidewalks and spontaneously trampled paths, the proportion of such species as Polygonum aviculare and Eragrostis minor is increasing. On average, 8-9 species are recorded in each vegetation plots, their total number in the coenoflora reaches 28 .

\section{Association Sisymbrietum loeselii Gutte 1972}

D.s.: Bromopsis inermis (Leyss.) Holub (Bromus inermis Leyss.), Carex caryophyllea Latourr., Sisymbrium loeselii.

Coenoses of this association are sporadically distributed on mechanically slightly disturbed chernozems and sandy soils, mainly along roads, less often on lawns of all administrative districts of Kyiv. The stands are dense (80-90\%), 120-130 cm in height, and are formed by diagnostic species (Sisymbrium loeselii) and other annual and biennial ruderal herbaceous plants. Among them, the most common are Chenopodium album, Conyza canadensis, Ambrosia artemisiifolia, Berteroa incana, and Bromopsis inermis. Polygonum aviculare and Plantago major are typical in the areas of moderate trampling. The coenoses are rich in species, due to the high content of nutrients in the substrates. Some plant communities are formed by $12-15$ species, in total, the coenoflora is composed of 34 taxa. Comparisons with other territories showed the highest similarity with the phytocoenoses of the association described from Cherkasy (Osypenko, Shevchyk, 2001). In particular, a high similarity is characteristic of the diagnostic species group. The main difference is the high proportion of representatives of the psammophytic florocoenocomplex (Chondrilla juncea, Artemisia campestris, Hylotelephium argutum (Haw.) Holub) in the floristic composition of the association in Kyiv.

According to the DCA-ordination results (Fig. 2), it was found that for Stellarietea mediae plant communities in Kyiv, the main factors determining their ecological differentiation are the salt regime of edaphotope, as well as aridity-humidity, cryo- and thermal regimes of the climate, vectors of which were closest to the first ordinance axis. 
Phytoindication analysis of Stellarietea mediae plant communities by the factor of soil humidity (Fig. 3) demonstrated that the majority of phytocoenoses of this class grow under conditions of insufficient moisture and are submesophytic. Only a few associations of the Atriplicion alliance, which appear at an intermediate succession stage and are replaced by Artemisietea vulgaris communities, are characterized by higher soil humidity requirements and occupy mesophytic habitats. The distribution of associations depending on the variability of damping (Fig. 4) shows that the phytocoenoses of the studied class are formed mainly in dry ecotopes, with irregular moistening of the soil root layer. Differentiation of Stellarietea mediae coenoses in relation to the soil aeration (Fig. 5) mostly revealed their subaerophylity. Only the coenoses of Cynodontetum dactyli, Eragrostio-Amaranthetum albi, and Hyoscyamo nigri-Malvetum neglectae, which are confined mainly to loamy soils, are hemiaerophobic.

Phytoindication analysis by the $\mathrm{pH}$ of the soil solution (Fig. 6) showed that the plant communities of the class are common on neutral or slightly acidic soils. The distribution of Stellarietea mediae associations in relation to the total salt regime of the substrate (Fig. 7) showed that they all prefer soils with a sufficient level of mineral nutrients. The results of phytoindication by the carbonate content (Fig. 8) allowed us to establish that the coenoses of the class either avoid carbonate substrates or are able to tolerate a low content of carbonates in the soil. The distribution of associations by the nitrogen content in the soil (Fig. 9) indicates their predominant heminitrophilicity. Nitrophilicity is more characteristic for some plant communities from Panico-Setarion, Atriplicion and Sisymbrion officinalis alliances, which are described from dumping sites.

Ecological differentiation of Stellarietea mediae associations according to the main parameters of the climate showed that the coenoses of this class in relation to the thermal regime are mainly submesothermic (Fig. 10), subaridophytic according to the aridityhumidity of the climate (Fig. 11), and hemicontinental by their continentality (Fig.12). The distribution of syntaxa by cryoregime revealed their subcryophility (Fig. 13), and the differentiation by the light regime of ecotopes (Fig. 14) showed that all phytocoenoses of the class are heliophytic.

\section{Conclusions}

The vegetation of the Stellarietea mediae class in Kyiv City is characterized by high coenotic diversity, which is due to the increased anthropogenic pressure and a large number of diverse ruderal habitats in the territory of the city. A total of 24 associations and 3 basal communities belonging to 8 alliances and 4 orders were identified. The largest areas in Kyiv are occupied by coenoses of the associations Ambrosio artemisiifoliae-Chenopodietum albi, Digitario sanguinalis-Eragrostietum minoris, Portulacetum oleracei, Chenopodietum stricti, Ambrosietum artemisiifoliae, Brometum tectorum, and Hordeetum murini. The plant communities of the class are generally similar to those reported for other cities of Ukraine. The highest similarity is characteristic at the level of dominant and constant species. The floristic composition of the co-occuring species depends on the intensity and scope of anthropogenic impact, soil types, and availability of water and mineral nutrition. Peculiarities of the coenotic structure of the investigated plant communities include polydominance and a high total cover of stands. Coenotaxonomic specificity is manifested by a significant representation of diagnostic species of other classes of anthropogenic vegetation (in particular, Artemisietea vulgaris, Galio-Urticetea, Polygono-Poetea annuae), as well as psammophytic floroelements in the spectra of the associations' coenofloras. The leading factors of territorial differentiation of Stellarietea mediae plant communities are, first of all, the type and intensity of anthropogenic disturbance, and, to a lesser extent, the soil types and their structure. The ecological distribution of syntaxa in the hyperspace of abiotic factors is determined by the salt regime of the edaphotope, aridity/ humidity of the climate, and cryo- and thermal regime of the environment. The developed syntaxonomic scheme, which reflects the ecological conditions of habitats, the main forming factors, trends of successions, and the structure of plant communities, and will be a component of the general Kyiv vegetation scheme, should be the basis for strategic planning and practical implementation of measures for sustainable socioeconomic and ecological development of the Kyiv urban ecosystem, optimization of the urban environment, and vegetation management to improve the quality of life in the city. 




Fig.3. Distribution of associations of the Stellarietea mediae class by soil humidity. Here and below in Figures 3 to 14, numbers on the horizontal ( $\mathrm{x}$, abscissa) axis correspond to the number of associations in the classification scheme, the values of ecological factors are indicated on the vertical (y, ordinate) axis

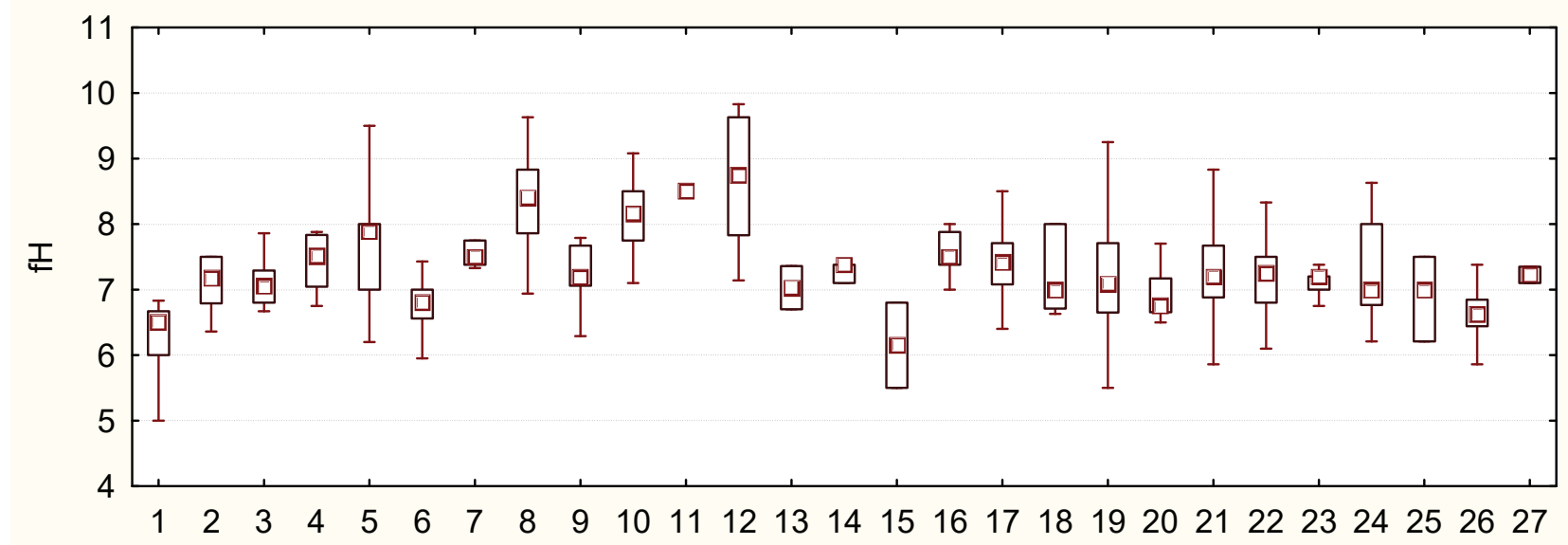

Fig.4. Distribution of associations of the Stellarietea mediae class by variability of damping



Fig.5. Distribution of associations of the Stellarietea mediae class by soil aeration 


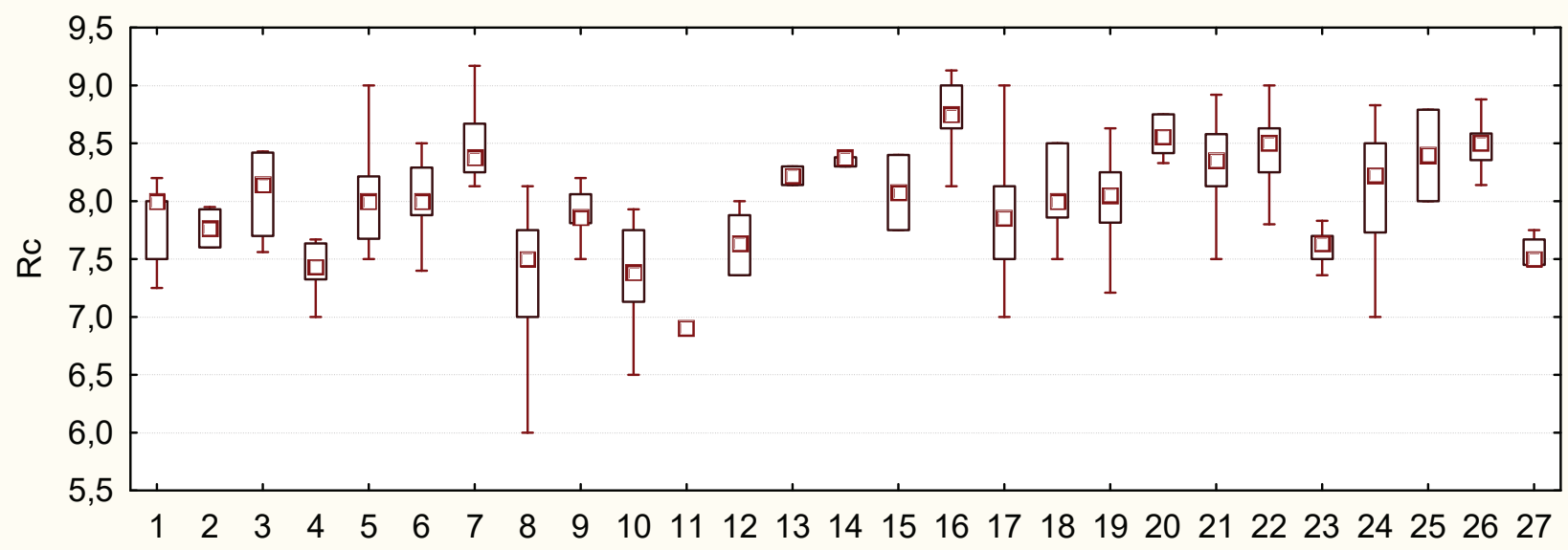

Fig.6. Distribution of associations of the Stellarietea mediae class by acidity

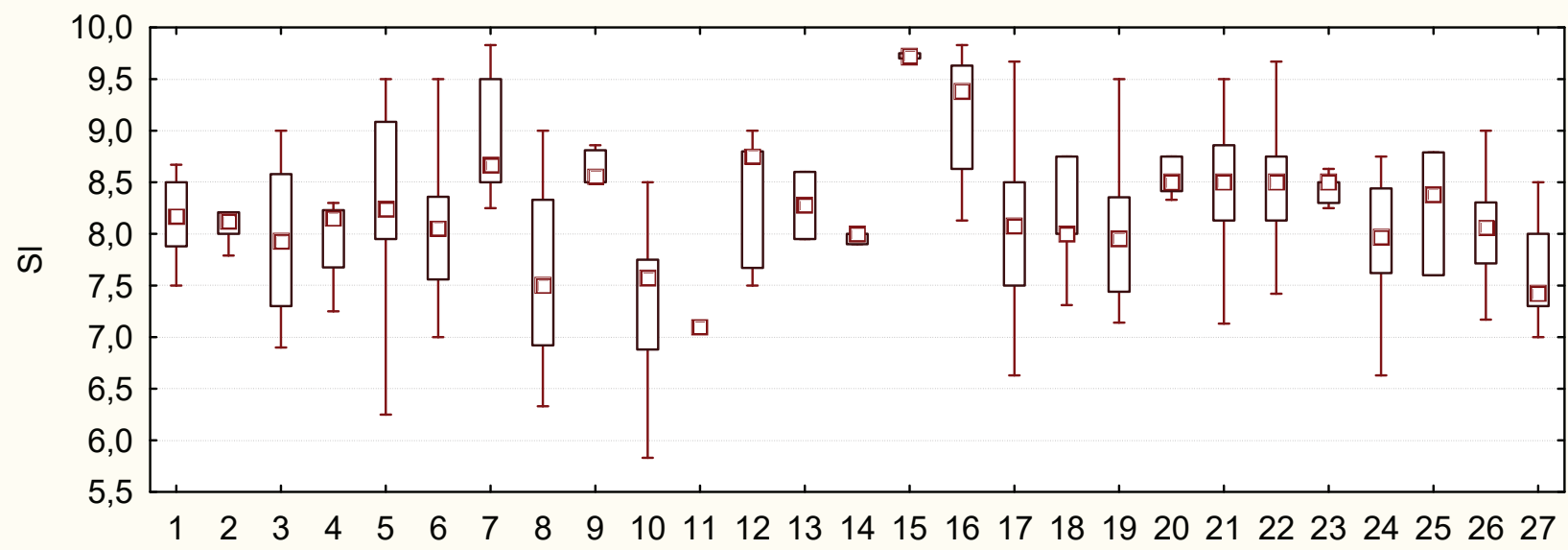

Fig.7. Distribution of associations of the Stellarietea mediae class by salt regime

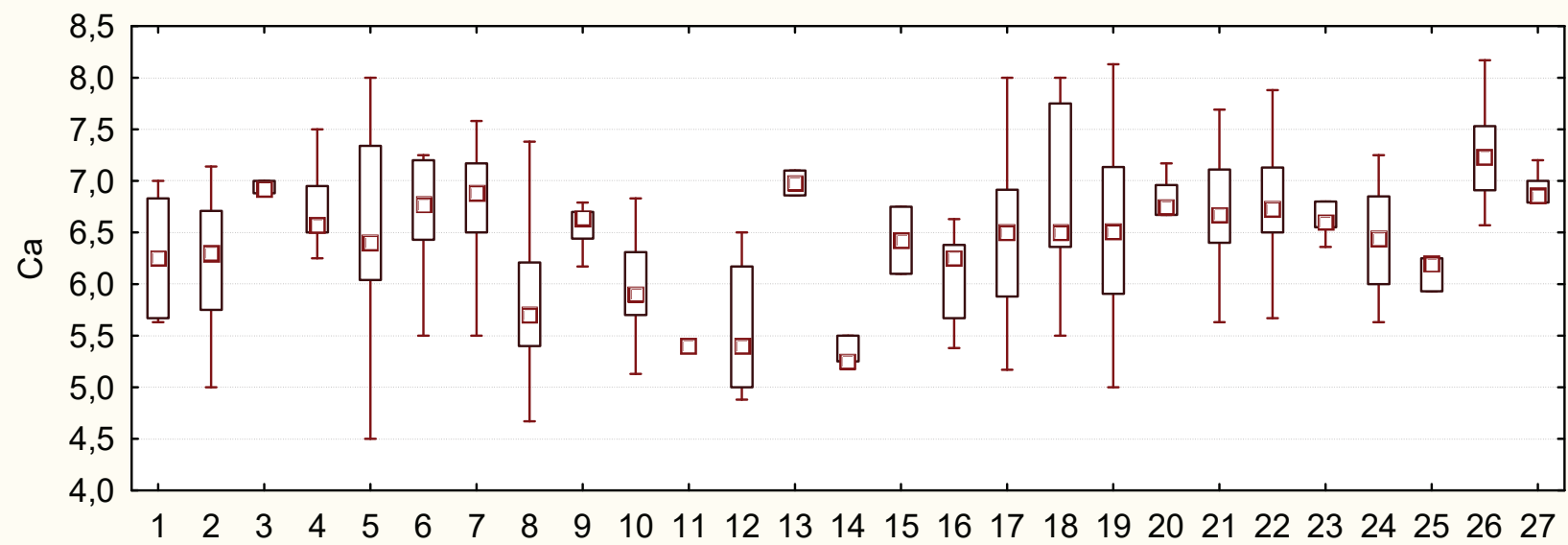

Fig.8. Distribution of associations of the Stellarietea mediae class by carbonate content 


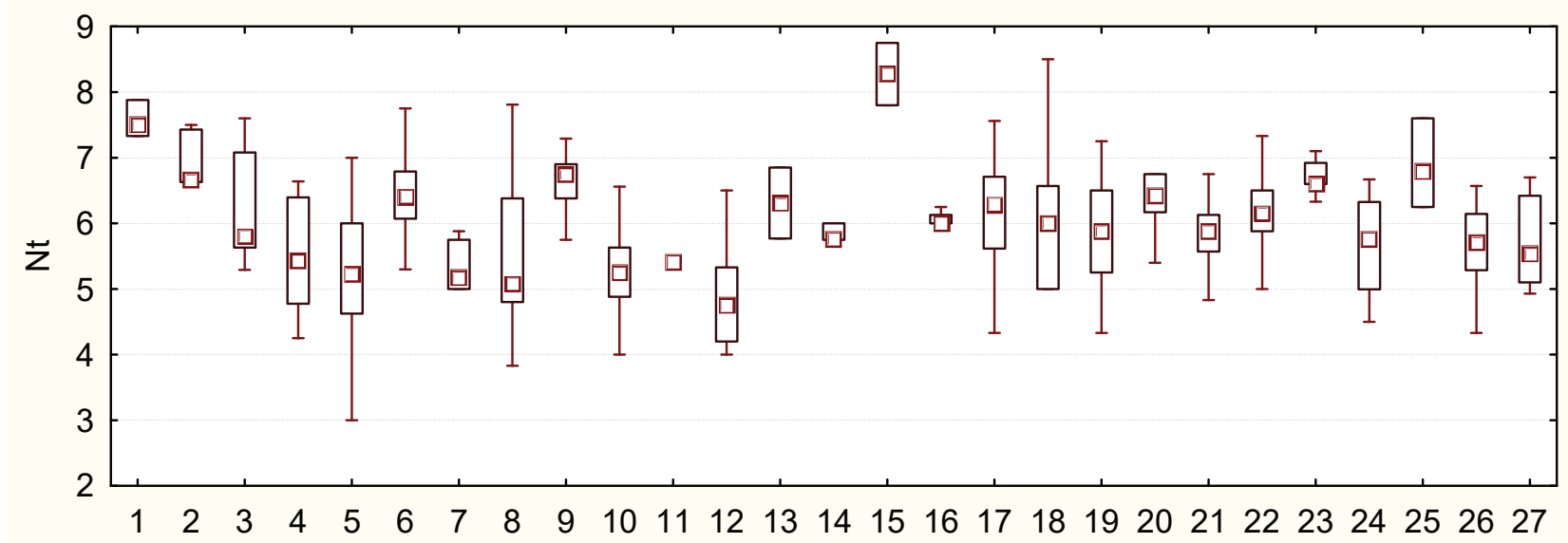

Fig.9. Distribution of associations of the Stellarietea mediae class by nitrogen content



Fig.10. Distribution of associations of the Stellarietea mediae class by thermoregime

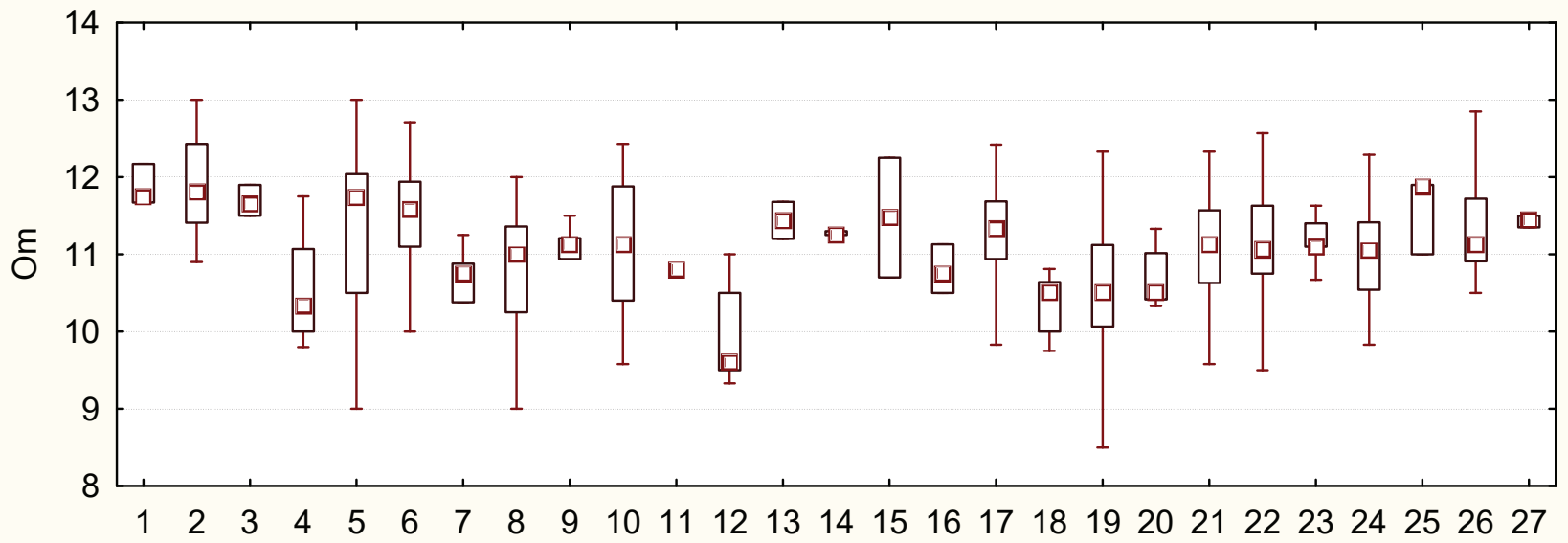

Fig.11. Distribution of associations of the Stellarietea mediae class by ombroregime 


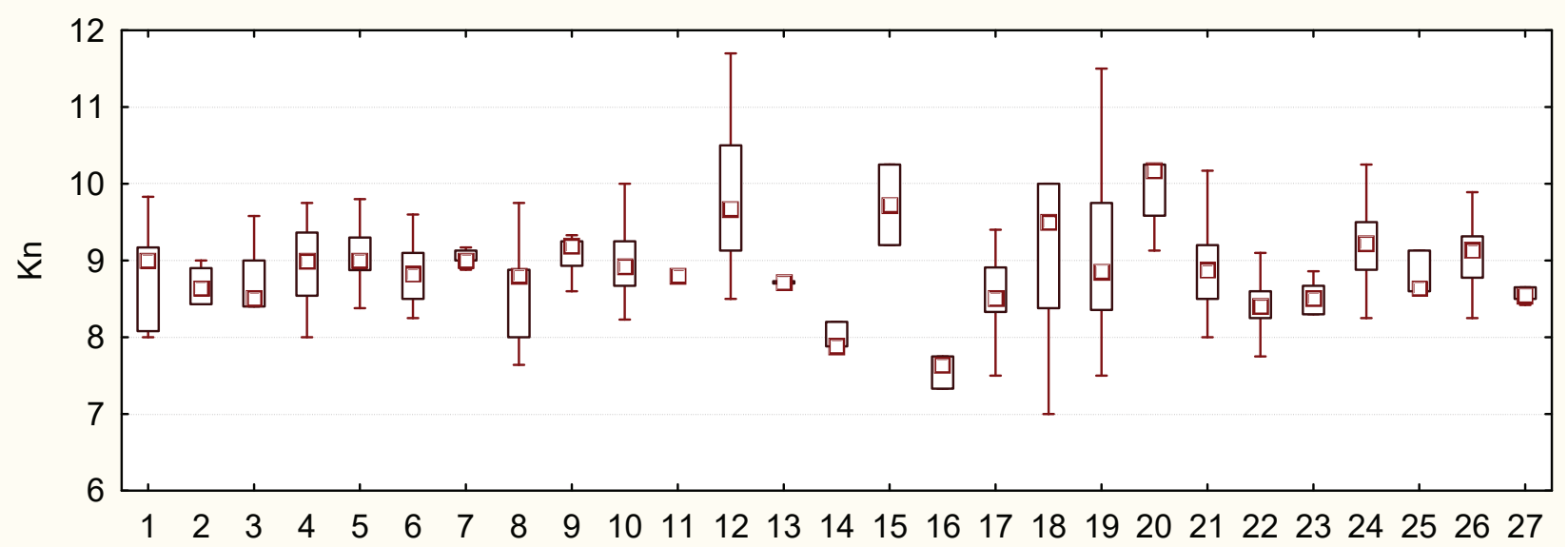

Fig.12. Distribution of associations of the Stellarietea mediae class by the continentality of climate

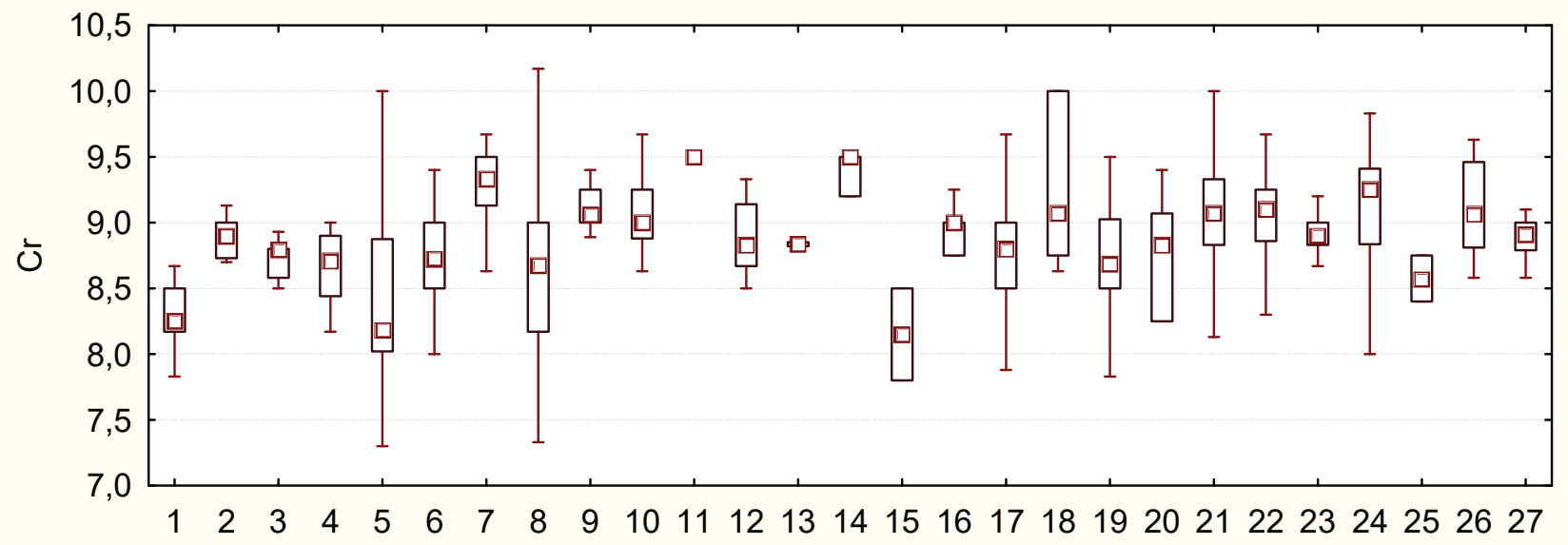

Fig.13. Distribution of associations of the Stellarietea mediae class by cryoregime

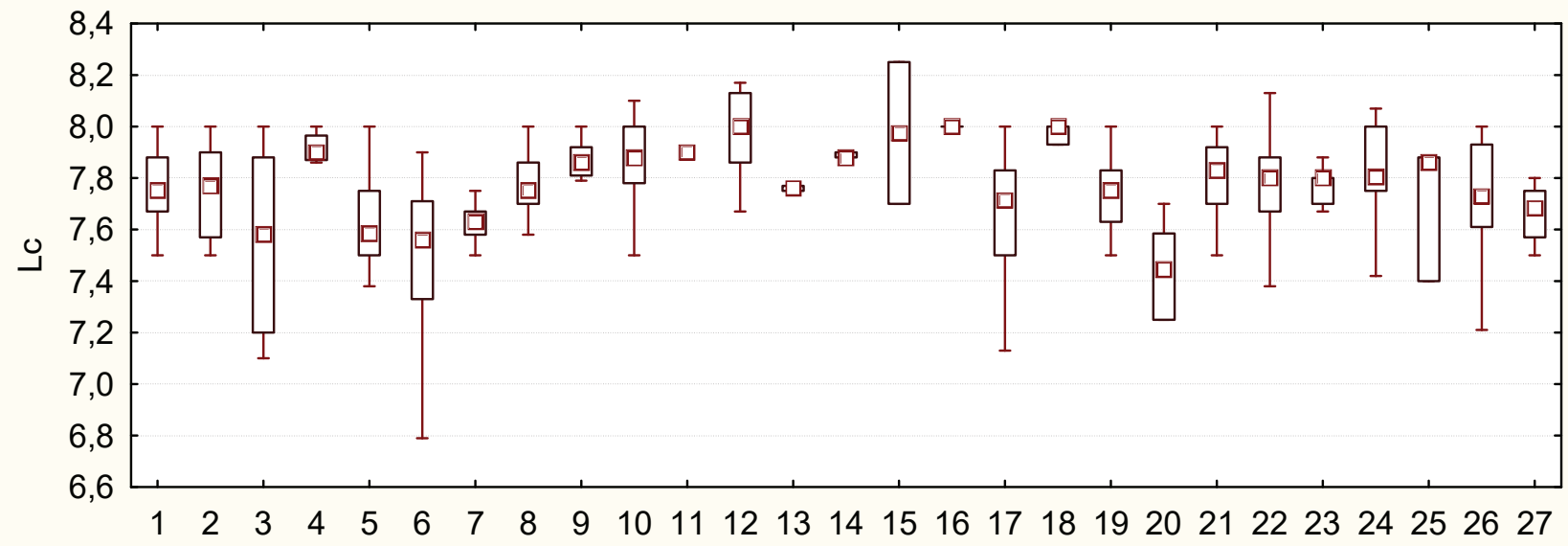

Fig.14. Distribution of associations of the Stellarietea mediae class by light regime of ecotopes 


\section{Acknowledgments}

The authors express their sincere gratitude to Prof. S.L. Mosyakin (M.G. Kholodny Institute of Botany, Kyiv), M.Sc. Elżbieta Obarska and Dr. hab. Zbigniew Celka (Adam Mickiewicz University, Poznań) for the help in editing the manuscript.

\section{References}

Abramova L.M. 2012. Izvestia of Samara Scientific Center of the Russian Academy of Sciences. 14(1-4): 945-949. [Абрамова Л.М. 2012. О классификации растительных сообществ с инвазивными видами. Известия Самарского научного иентра Российской академии наук. 14(1-4): 945-949].

Anioł-Kwiatkowska J. 1990. Zbiorowiska segetalne Wału Trzebnickiego. Florystyczno-ekologiczne stadium porównawcze. In: Floristic and ecological comparative study. Wrocław: Wydawnictwo Uniwersytetu Wrocławskiego, pp. 46-230.

Arepieva L.A. 2017. Vegetation of Russia, 30: 3-28. [АрепьеваЛ.А. 2017. Растительностьжелезнодорожных насыпей Курской области. Растительность России, 30: 3-28]. https://doi.org/10.31111/vegrus/2017.30.3

Arepieva L.A. 2019. Diversity of plant world, 2(2): 1837. [Арепьева Л.А. 2019. О новых синтаксонах синантропной растительности города Брянска. Разнообразие растительного мира, 2(2): 18-37]. https://doi.org/10.22281/2686-9713-2019-2-18-37

Bagrikova N.A. 2004. Ukrainian Phytosociological Collection. Series A, 1(21): 1-188. [Багрикова Н.A. 2004. Сорно-полевая растительность Крыма. Украӥнський фітоиенологічний збірник. Сер. A, 1(21): 1-188].

Braun-Blanquet J. 1964. Pflanzensoziologie. Grundzuge der Vegetationskunde. 3 Aufl. Wien; New York: SpringerVerlag, $865 \mathrm{pp}$.

Bredikhina Yu.L. Spontanna roslynnist m. Melitopolya: syntaksonomiya, fitomelioratyvne znachennya i shchlyakhy optymizatsii: Cand. Sci. Diss. Abstract. Lviv, 2015, 18 рр. [Бредіхіна Ю.Л. Спонтанна рослинність м. Мелітополя: синтаксономія, фітомеліоративне значення і шляхи оптимізації: автореф. дис. ... канд. сільськогосп. наук: спец. 06.03.01 "Лісові культури та фітомеліорація". Львів, 2015, 18 с.].

Bulokhov A.D., Ivenkova I.M., Panasenko N.N. 2019. Vestnik of Tver State University. Series: Biology and Ecology, 2(54): 103-122 [Булохов А.Д., Ивенкова И.М., Панасенко Н.Н. 2019. Сообщества класса Papaveretea rhoeadis S. Brullo et al. 2001 и Sisymbrietea Gutte et Hilbig 1975 в Южном Нечерноземье России. Вестник Тверскогогоссударственного университета. Серия: Биология и экология, 2(54): 103-122.]. https://doi. org/10.26456/vtbio 75
Chokha O.V. 2005. Hazonni pokryttya m. Kyeva. Kyiv: Phytosociocenter, 82 pp. [Чоха O.В. Газонні покриття м. Києва. Київ: Фітосоціоцентр, 82 с.].

Chokha O.V. 2007. Ecology and noospherology, 18(1-2): 36-50. [Чоха О.В. 2007. Синтаксономія рослинності газонів м. Києва. Клас Plantaginetea majoris. Екологія та ноосферологія. 18(1-2): 36-50].

Chytrý M., Tichý L., Holt J., Botta-Dukát Z. 2002. Determination of diagnostic species with statistical fidelity measures. Journal of Vegetation Science, 13: 79-90. https://doi.org/10.1111/j.1654-1103.2002.tb02025.x

Chytrý M., Danihelka J., Kaplan Z., Wild J., Holubová D., Novotný P., Řezníčková M., Rohn M., Dřevojan P., Grulich V., Klimešová J., Lepš J., Lososová Z., Pergl J., Sádlo J., Šmarda P., Štěpánková P., Tichý L., Axmanová I., Bartušková A., Blažek P., Chrtek J. Jr., Fischer F. M., Guo W.-Y., Herben T., Janovský Z., Konečná M., Kühn I., Moravcová L., Petřík P., Pierce S., Prach K., Prokešová H., Štech M., Těšitel J., Těšitelová T., Večeřa M., Zelený D., Pyšek P. 2021. Pladias Database of the Czech Flora and Vegetation. Preslia, 93: 1-87. https://doi.org/10.23855/ preslia.2021.001

Didukh Ya.P. 2011. The ecological scales for the species of Ukrainian flora and their use in synphytoindication. Kyiv: Phytosociocentre, $176 \mathrm{pp}$.

Didukh Ya.P., Chumak K.V. 1992. Ukrainian Botanical Journal, 49(6): 22-27. [Дідух Я.П., Чумак К.В. 1992. Геоботанічна характеристика заказника "Лісники" (м. Київ). Український ботанічний журнал, 49(6): 22-27].

Dubyna D.V., Dziuba T.P., Iemelianova S.M., Bagrikova N.O., Borysova O.V., Borsukevych L.M., Vynokurov D.S., Gapon S.V., Gapon Yu.V., Davydov D.A., Dvoretskyi T.V., Didukh Ya.P., Zhmud O.I., Kozyr M.S., Konishchuk V.V., Kuzemko A.A., Pashkevych N.A., Ryff L.E., Solomakha V.A., Felbaba-Klushyna L.M., Fitsailo T.V., Chorna H.A., Chorney I.I., Shelyag-Sosonko Yu.R., Iakushenko D.M. 2019. Prodrome of the Vegetation of Ukraine. Eds D.V. Dubyna, T.P. Dziuba. Kyiv: Naukova Dumka, 782 pp. [Дубина Д.В., Дзюба Т.П., Ємельянова С.М., Багрікова Н.О., Борисова О.В., Борсукевич Л.М., Винокуров Д.С., Гапон С.В., Гапон Ю.В., Давидов Д.А., Дворецький Т.В., Дідух Я.П., Жмуд О.І., Козир М.С., Коніщук В.В., Куземко А.А., Пашкевич Н.А., Рифф Л.Е., Соломаха В.А., ФельбабаКлушина Л.М., Фіцайло Т.В., Чорна Г.А., Чорней I.I., Шеляг-Сосонко Ю.Р., Якушенко Д.М. 2019. Продромус рослинності України. Відп. ред. Д.В. Дубина, Т.П. Дзюба. Київ: Наукова думка, 782 с.].

Dubyna D.V., Ennan A.A., Dziuba T.P., Vakarenko L.P., Kiriushkyna H.M., Shykhaleeva H.M. 2018. Chornomorskyi Botanical Journal, 14 (3): 562-573. [Дубина Д.В., Еннан А.А., Дзюба Т.П., Вакаренко Л.П., Кірюшкина Г.М., Шихалєєва Г.М. 2018. Синтаксономія рудеральної рослинності долини Куяльницького лиману. Чорноморський ботанічний журнал. 14 (3): 562-573]. https://doi.org/10.14255/2308-9628/18.143/4

Dubyna D.V., Neuhäyslova Z., Dziuba T.P., Shelyag-Sosonko Yu.R. 2004. Klasyfikatsiya ta prodromus roslynnosti 
vodoym, perezvolozhenykh terytoriy ta aren Pivnichnoho Prychornomor'ya. Kyiv: Phytosociocenter, 200 pp. [Дубина Д.В., Нойгойзлова 3., Дзюба Т.П., ШелягСосонко Ю.Р. 2004. Класифікачія та продромус рослинності водойм, перезволожених територій та арен Північного Причорномор'я. Київ: Фітосоціоцентр, 200 c.].

Dziuba T.P., Dubyna D.V., Tymoshenko P.A., Iemelianova S.M. 2019. In: Synanthropization of the vegetation cover of Ukraine: III All-Ukrainian Scientific Conference: book of scientific articles. Kyiv, pp. 42-47. [Дзюба Т.П., Дубина Д.В., Тимошенко П.А., Смельянова С.М. 2019. Рудеральна рослинність залізничних шляхів міста Києва. В зб.: Синантропізачія рослинного покриву України: ІІІ Всеукраїнська наукова конференція:збірник наукових статей. Київ, с. 42-47].

Dziuba T.P., Solomakha T.D., Tymoshenko P.A. 2010. Roslynni uhrupovannya. In: PereyaslavKhmelnytskyi. Pryroda: roslynnyi svit; Eds. V.P. Kotsur, V.M. Dzhuran, M.M. Fedoronchuk, M.V. Shevera. Korsun-Shevchenkivskyi: FOP Maydanchenko I.S., pp: 86-95. [Дзюба Т.П., Соломаха Т.Д., Тимошенко П.А. 2010. Рослинні угруповання. В кн.: ПереяславХмельницький. Природа: рослинний світ; за ред. В.П. Коцура, В.М. Джурана, М.М. Федорончука, M.В. Шевери. Корсунь-Шевченківський: ФОП Майданченко I.C., С. 86-95].

Epikhin D.V. 2006. Ekosistemy Kryma, ikh optimizatsiya $i$ okhrana, 16: 127-135. [Епихин Д.В. 2006. Синантропная растительность города Симферополя. Экосистемь Крыма, их оптимизащия и охрана, 16: 127-135].

eVeg - a database upon European vegetations. Available at: https://www.e-veg.net/app/15021 (Accessed 15 June 2020).

Golovanov Ya.M., Abramova L.M. 2018. Samarskaya Luka: problemy regionalnoy i globalnoy ekologii, 27(4): 137-143. [Голованов Я.М., Абрамова Л.М. 2018. Разнообразие растительности городов южной промышленной зоны Республики Башкортостан. Самарская Лука: проблемы региональной и глобальной экологии, 27(4): 137-143]. https://doi.org/10.24411/2073-1035-2018-10102

Goncharenko I., Yatsenko G. 2020. Phytosociological study of the forest vegetation of Kyiv urban area (Ukraine). Hacquetia, 19/1: 99-126. $\quad$ https://doi.org/10.2478/ hacq-2019-0012

Goncharenko I.V., Kozyr M.S., Senchylo O.O. 2020. Classification of the floodplain meadows of the Seym and the Dnieper river valleys in the north-eastern part of Ukraine. Biologia (Bratislava), 75 (1): 53-70. https://doi. org/10.2478/s11756-019-00361-5

Goncharenko I.V., Holyk G.M. 2015. Phytodiversity of Eastern Europe, 9(4): 129-158. [Гончаренко И.В., Голик Г.Н. 2015. Классификация и фитоэкологическая оценка лесопарковой растительности г. Киева. Фиторазнообразие Восточной Европь. 9(4): 129-158].

Grechyshkina Yu.V. 2010. The Native Flora of Kyiv City: Cand. Sci. Diss. Abstract. Kyiv, M.G. Kholodny Institute of Botany NAS of Ukraine, 23 pp. [Гречишкіна Ю.В. 2010. Природна флора судинних рослин м. Києва: автореф. дис. ... канд. біол. наук: спец. 03.00.05 "Ботаніка". Київ, Інститут ботаніки ім. М.Г. Холодного НАН України, $23 \mathrm{c.}$.]

Hamor F.D. 1987. Ukrainian Botanical Journal, 44 (5): 3643. [Гамор Ф.Д. 1987. Класифікація видів та угруповань сегетальної рослинності Закарпаття. Украӥнський ботанічний журнал, 44 (5): 36-43].

Hennekens S.M., Schaminée J. 2001. TURBOVEG, a comprehensive data base management system for vegetation data. Journal of Vegetation Science, 12: 589591. https://doi.org/10.2307/3237010

Hill M.O., Gauch H. 1980. Detrended correspondence analysis, an improved ordination technique Vegetatio, 42: 47-58. https://doi.org/10.1007/BF00048870

Holyk G.M., Goncharenko I.V. 2017. Ecology and noospherology, 28(1-2): 49-63. [Голик Г.М., Гончаренко I.В. 2017. Синтаксономія деревної рослинності м. Київ, іï синфітоіндикаційний аналіз та антропогенна трансформація. Екологія та ноосферологія, 28(1-2): 49-63]. https://doi. org/10.15421/031705

Gomlya L.M. 2005. Ukrainian Phytosociological Collection. Series A, 1(22): 1-187. [Гомля Л.М. 2005. Рослинність долини річки Хорол. Украйнський фітоиенологічний збірник. Сер. А., 1 (22): 1-187].

Ishbirdin A.R., Mirkin B.M., Solomeshch A.I., Sakhapov M.T. 1988. Sintaksonomiya, ekologiya i dinamika ruderalnikh soobshchestv Bashkirii. Ufa, 161 pp. [Ишбирдин А.P., Миркин Б.М., Соломещ А.И., Сахапов М.Т. 1988. Синтаксономия, екология и динамика рудеральних сообществ Башкирии. Уфа, 161 с.].

Kopecký K., Hejný S. 1974. A new approach to the classification of anthropogenic plant communities. Vegetatio, 29: 17-20. https://doi.org/10.1007/BF02390892

Kozyr M.S. 2013. Ekosystemy, yikh optymizatsiya ta okhorona, 8: 71-77. [Козир М.С. 2013. Лісова рослинність урочища Лиса Гора (м. Київ). Екосистеми, їх оптимізація та охорона, 8: 71-77].

Kozyr M.S., Zhyhalenko O.A., Kalyta H.O. 2017. Chornomorskyi Botanical Journal, 13 (1): 57- 71. [Козир М.С., Жигаленко О.А., Калита Г.О. 2017. Луки заплавних комплексів м. Київ. Чорноморський ботанічний журнал, 13(1): 57-71]. https://doi. org/10.14255/2308-9628/17.131/5

Kozyr N.S. 2012. In: Populyatsiyna ekolohiya roslyn: suchasnyi stan, tochky rostu. Sumy: Sumskyi natsionalnyi ahrarnyi universytet, pp. 65-70. [Козырь Н.С. Синтаксономия лесной растительности природнозаповедного фонда г. Киев. В зб.: Популяційна екологія рослин: сучасний стан, точки росту: збірник наукових cmaтей. Суми: Сумський національний аграрний університет, с. 65-70].

Kucheryavyi V.O., Solomakha V.A., Solomakha T.D., Shelyag-Sosonko Yu.R., Kramarets V.O. 1991.Ukrainian Botanical Journal, 48 (3): 48-55. [Кучерявий B.O., Соломаха В.А., Соломаха Т.Д., Шеляг-Сосонко Ю.Р., Крамарець В.О. 1991. Синтаксономія рудеральної 
рослинності м. Львова. Украӥнський ботанічний журнал, 48 (3): 48-55].

Küzmič F., Šilc U., Lososová Z., Mucina L. \& numerous data contributors. 2018. An overview of the European annual weed vegetation In: Vegetation survey 90 years after the publication of Braun-Blanquet's textbook-new challenges and concepts: Book of Abstracts. 27th Congress of the European Vegetation Survey. Wrocław, p. 126.

Landucci F., Šumberová K., Tichý L., Hennekens S., Aunina L., Biță-Nicolae C., Borsukevych L., Bobrov A., Čarni A., De Bie E., Golub V., Hrivnák R., Iemelianova S., Jandt U., Jansen F., Kącki Z., Lájer K., Papastergiadou E., Šilc U., Sinkevičienè Z., Stančić Z., Stepanovič J., Teteryuk B., Tzonev R., Venanzoni R., Zelnik I., Chytrý M. 2020. Classification of the European marsh vegetation (Phragmito-Magnocaricetea) to the association level. Applied Vegetation Science, 23: 1-20. http://dx.doi. org/10.1111/avsc. 12484

Levon O.F. 1999. The synanthropic vegetation of the territory of Great Yalta: Cand. Sci. Diss. Abstract. Kyiv, M.M. Gryshko National Botanical Garden, 16 pp. [Левон О.Ф. Синантропна рослинність території Великої Ялти: автореф. дис. ... канд. біол. наук: спец. 03.00.05 "Ботаніка". Київ, Національний ботанічний сад ім.. М.М. Гришка, 1999. 16 с.].

Ługowska M., Skrajna T. 2013. Weed communities in potato (Solanum tuberosum L.) crops of the Mazowiecki landscape park. Acta agrobotanica, 66(1): 119-134. http:// doi.org/10.5586/aa.2013.014

Marceno C., Guarino R., Loidi J., Herrera M., Isermann M., Knollová I., Tichý L., Tzonev R., Acosta A.T.R., FitzPatrick Ú., Iakushenko D., Janssen J.A.M., JiménezAlfaro B., Kącki Z., Keizer-Sedláková I., Kolomiychuk V., Rodwell J.S., Schaminée J.H.J., Šilc U., Chytrý M. Classification of European and Mediterranean coastal dune vegetation. 2018. Applied Vegetation Science. 21 (1): 1-27. https://doi.org/10.1111/avsc. 12379

McCune B., Mefford M.J. 2006. PC-ORD. Multivariate analysis of ecological data. Version 5. Gleneden Beach, Oregon, U.S.A.: MjM Software, 24 pp.

Mirkin B.M., Rozenberg G.S., Naumova L.G. 1989. Slovar ponyatiy $i$ terminov sovremennoy fitotsentologii. Moskva: Nauka, 223 pр. [Миркин Б.М., Розенберг Г.С., Наумова Л.Г. 1989. Словарь понятий и терминов современной фитоцентологии. Москва: Наука, 223 с.].

Mochnacký S. 1982. Burinové spoločenstvá Východoslovenskej niţiny. Záverečná správa, mscr. Depon. in Ústav krajinnej ekológie SAV, Bratislava.

Mosyakin S., Fedoronchuk M. 1999. Vascular plants of Ukraine. A nomenclatural checklist. Kiev, 345 pp.

Mosyakin S.L., Yavorska O.H. 2002. The nonnative flora of the Kyiv (Kiev) Urban Area, Ukraine: A checklist and brief analysis. Urban Habitats, 1(1): 45-65. Available at: http:// www.urbanhabitats.org/v01n01/nonnativekiev_pdf.pdf

Mucina L., Bültmann H., Dierßen K. Theurillat J.-P., Raus T., Čarni A., Šumberová K., Willner W., Dengler J., Gavilán García R., Chytrý M., Hájek M., Di Pietro R.,
Iakushenko D., Pallas J., Daniëls F.J.A., Bergmeier E., Santos Guerra A., Ermakov N., Valachovič M., Schaminée J.H.J., Lysenko T., Didukh Y.P., Pignatti S., Rodwell J.S., Capelo J., Weber H.E., Solomeshch A., Dimopoulos P., Aguiar C., Hennekens S.M., Tichý L. 2016. Vegetation of Europe: hierarchical floristic classification system of vascular plant, bryophyte, lichen, and algal communities. Applied Vegetation Science. 19 (1): 1-783. https://doi.org/10.1111/avsc.12257

Nazarov M, Vassilev K, Gecheva G, Mardari C., Velev N. 2019. Syntaxonomical diversity of Strazhata hill in the central part of north Bulgaria. In: Vegetation Diversity and Global Change: Book of Abstracts. 28th Meeting of the European Vegetation Survey. Madrid, 34 p.

Oliynyk M.P., Gubar L.M. 2019. Syntaxonomy of plant communities with diagnostic species of genus Elytrigia. Chornomorskyi Botanical Journal, 15(1): 26-35. https:// doi.org/10.32999/ksu1990-553X/2019-15-1-3

Onyshchenko V.A. 2011. Scientific Herald of Chernivtsy University. Biology (Biological Systems), 3(1): 56-75. [Онищенко В.А. 2011. Рослинність ур. Теремки (НПП "Голосіївський", м. Київ). Вісник Чернівецьького Університету. Біологічні системи. 3(1): 56-75].

Onyshchenko V.A. 2013a. Scientific Herald of Chernivtsy University. Biology (Biological Systems), 5(1): 93116. [Онищенко В.А. 2013а. Лісова рослинність ур. Голосіївський ліс (м. Київ). Вісник Чернівецького Університету. Біологічні системи, 5(1): 93-116].

Onyshchenko V.A. 2013b. Scientific Herald of Chernivtsy University. Biology (Biological Systems), 5(3): 395-403. [Онищенко В.А. 2013b. Рослинність ур. Бичок (НПП "Голосіївський", м. Київ). Вісник Чернівецького Університету. Біологічні системи, 5(3): 395-403].

Osypenko V.V. 1996. Ukrainian Phytosociological Collection. Series A, 2(2): 88-92. [Осипенко В.В. 1996. Спонтанна рослинність м. Черкаси. 1: Рослинність клумб. Украӥнський фіточенологічний збірник. Серія А, 2(2): 88-92].

Osypenko V.V. 1997. Ukrainian Phytosociological Collection. Series A. 2(7): 89-95. [Осипенко В.В. 1997. Спонтанна рослинність м. Черкаси. 3: Угруповання селітебних територій. Украӥнський фітоценологічний збірник. Серія А. 2(7): 89-95].

Osypenko V.V. 1999. Ukrainian Phytosociological Collection. Series A, 3(14): 107-122. [Осипенко В.В. 1999. Спонтанна рослинність м. Черкаси. 5. Угруповання рудеральної рослинності. Український фітоиенологічний збірник. Серія A, 3(14): 107-122].

Osypenko V.V. Spontanna roslynnist m. Cherkasy: Cand. Sci. Diss. Abstract. Kyiv, 2006, 20 pp. [Осипенко В.В. Спонтанна рослинність м. Черкаси: автореф. дис... канд. біол. наук: спец. 03.00.05 "Ботаніка". Київ, 2006, 20 c.].

Osypenko V.V., Shevchyk V.L. 2001. Ukrainian Phytosociological Collection. Series A, 1(17): 104121. [Осипенко В.В., Шевчик В.Л. 2001. Спонтанна рослинність м. Черкаси. 6. Рудеральна рослинність прибережної частини м. Черкаси. Український фіточеенотичний збірник. Серія А, 1(17): 104-121].

Ukrainian Botanical Journal, 2021, 78(3) 
Otte A. 1984. Bewirtschaftungsgradienten in Sandmohnund Fingerhirse-Gesellschaften (Papaveretum argemone, Digitarietum ischaemi) im Tertiären Hügelland (Oberbayern). Tuexenia, 4: 103-124.

Papucha I.V. 1991. Ukrainian Botanical Journal, 48(2): 39-41. [Папуча I.В. 1991. Рудеральна рослинність м. Чернігова. Украӥнський ботанічний журнал, 48(2): 39-41].

Pashkevych N.A. 2012. In: Synanthropization of the vegetation cover of Ukraine: II All-Ukrainian Scientific Conference: book of scientific articles. Kyiv; PereyaslavKhmelnytskyi, pp. 71-74. [Пашкевич Н.A. 2012. Екологічні особливості розподілу рудеральних угруповань однорічних злаків у Києві та Київській області. В зб.: Синантропізаиія рослинного покриву України: тези наукових доповідей II Всеукраїнської наукової конференції. Київ, Переяслав-Хмельницький, c. 71-74].

Roleček J., Tichý L., Zelený D., Chytrý M. 2009. Modified TWINSPAN classification in which the hierarchy respects cluster heterogeneity. Journal of Vegetation Science, 20: 596-602. https://doi. org/10.1111/j.1654-1103.2009.01062.x

Shmidt V.M. 1980. Statisticheskie metody v sravnitelnoy floristike, Leningrad, 176 pp. [Шмидт B.M. 1980. Статистические методы в сравнительной флористике, Ленинград, 176 с.].

Smetana M.H. 2002. Syntaksonomiya stepovoi ta ruderalnoi roslynnosti Kryvorizhzhya. Kryvyi Rih: I.B.I. Publ., 131 pр. [Сметана М.Г. 2002. Синтаксономія степовоі та рудеральної рослинності Криворіжжя. Кривий Ріг: I.B.I., 131 c.].

Sørensen T.J. 1948. A method of establishing groups of equal amplitude in plant sociology based on similarity of species content and its application to analyses of the vegetation of Danish commons. Kongelige Danske Videnskabernes Selskab, Biologiske Skrifter, 5(4): 1-34.

Soroka M.I. 2008. Roslynnist Ukrainskoho Roztochchya. Lviv: Svit, 434 pp. [Сорока M.I. 2008. Рослинність Українського Розточчя. Львів: Світ, 434 с.].

Stetsyuk V.V., Romanchuk S.P., Shchur Yu.V., Dmytruk O.Yu., Hutsal V.O. 2001. Kyiv yak ekolohichna systema: pryroda - lyudyna - vyrobnytstvo - ekolohiya. Kyiv: Tsentr ekol. osvity ta informatsii, 315 pp. [Стецюк В.В., Романчук С.П., Щур Ю.В., Дмитрук О.Ю., Гуцал В.О. 2001. Київ як екологічна система: природа -людинавиробництво - екологія. Київ: Центр екол. освіти та інформації, 315 с.].

Tichý L. 2002. JUICE, software for vegetation classification. Journal of Vegetation Science, 13: 451-453. https://doi. org/10.1111/j.1654-1103.2002.tb02069.x

Tokaryuk A.I. 2019. Biological systems, 11(2): 228-242. [Токарюк А.I. 2019. Адвентивні види у рослинному покриві парку-пам'ятки садово-паркового мистецтва місцевого значення "Парк "Жовтневий" м. Чернівці. Biological systems, 11(2): 228-242].

Tsap'yuk L.M. 2012. In: Synanthropization of the vegetation cover of Ukraine: II All-Ukrainian Scientific Conference: book of scientific articles. Kyiv; Pereyaslav-Khmelnytskyi, pp. 83-84. [Цап'юк Л.М. 2012. Синтаксономія синантропної рослинності заплави р. Бистриці Солотвинської в межах м. Івано-Франківська. В зб.: Синантропізація рослинного покриву Украйни: тези наукових доповідей II Всеукраӥнської наукової конференції. Київ; Переяслав-Хмельницький, C. 83-84].

Tsukanova G.O. 2005. Floristic and conotic diversity of the Dnieper islands within Kyiv and its protection: Cand. Sci. Diss. Abstract. Kyiv, M.G. Kholodny Institute of Botany NAS of Ukraine, 20 pp. [Цуканова Г.О. 2005. Флористичне та ценотичне різноманіття островів Дніпра в межах м. Києва та його охорона: автореф. дис. ... канд. біол. наук: спец. 03.00.05. 03.00.05 "Ботаніка". Київ, Інститут ботаніки ім. М.Г. Холодного НАН України, 20 с.].

Tüxen R. 1950. Grundriß einer Systematik der nitrophilen Unkrautgesellschaften in der Eurosibirischen Region Europas. Mitteilungen der Floristisch-Soziologischen Arbeitsgemeinschaft, 2: 94-175. https://www.zobodat.at/ pdf/Mitt-flori-soz-Arb_NF_2_0094-0175.pdf

Viţălariu Gh. 1973. Contribuţii la cunoaşterea vegetaţiei ruderale din Moldova. Studii şi Comunicări, Muzeul de Ştiinţele Naturii Bacău, 23(5): 333-342.

Weber H.E., Moravec J., Theurillat J.-P. 2000. International Code of Phytosociological Nomenclature. $3^{\text {rd }}$ ed. Journal of Vegetation Science, 11: 739-768. https://doi. org $/ 10.2307 / 3236580$

Whittaker R.H. 1978. Approaches to classifying vegetation on classification of plant communities (Ed. R.H. Whittaker). $2^{\text {nd }}$ ed. The Hague: Junk, 31 pp. https://doi. org/10.1007/978-94-009-9183-5

Yavorska O.H., Mosyakin S.L. 2001. Naukovi zapiski Natsionalnoho universytetu "Kievo-Mohylyanska akademiya". Seriya: Biologiya ta Ekolohiya, 19: 5568. [Яворська О.Г., Мосякін С.Л. 2001. Адвентивна фракція синантропної флори Київської агломерації. Наукові записки Національного університету "КиєвоМогилянська академія". Серія: Біологія та екологія, 19: 55-68].

Yeremenko N.S. 2018. Ukrainian Botanical Journal, 75(4): 356-372. [Єременко Н.С. 2018. Рудеральна рослинність міста Кривий Ріг. II. Клас Stellarietea mеdiaе. Український ботанічний журнал, 75(4): 356372]. https://doi.org/10.15407/ukrbotj75.04.356

Recommended for publication by M.M. Fedoronchuk 
Дубина Д.В., Смельянова С.М., Дзюба Т.П., Сременко Н.С., Тимошенко П.А. 2021. Рудеральна рослинність м. Київ. I. Клас Stellarietea mediae Tx. et al. in Tx. 1950. Украӥнський ботанічний журнал, 78(3): 176-200 [In English].

Інститут ботаніки ім. М.Г. Холодного НАН України, вул. Терещенківська 2, Київ 01601, Україна

Реферат. У статті представлені результати дослідження угруповань класу Stellarietea mediae на території міста Києва. 3'ясовано їх сучасний стан і встановлено фітоценотичне різноманіття. На основі сучасних методів статистичного аналізу даних розроблено класифікаційну схему рослинності Stellarietea mediae на дослідженій території, а також виявлені провідні фактори територіальної та екологічної диференціації угруповань. Встановлено, що в межах Києва клас представлений 24 асоціаціями та 3 базальними угрупованнями, що належать до 8 союзів на 4 порядків. Їх територіальний розподіл визначають характер та інтенсивність антропогенних порушень, а також тип субстрату та його механічний склад. Охарактеризовані виділені синтаксономічні одиниці та виявлені їх особливості порівняно з аналогічними описаними на території України. Встановлено, що основні відмінності проявляються на рівні супутніх видів склад яких значною мірою корелює із типами антропогенних порушень та забезпеченістю субстратів, де поширені угруповання класу, елементами водно-мінерального живлення. За результатами проведеного ординаційного аналізу встановлено, що розподіл рослинних угруповань Stellarietea mediae відбувається вздовж градієнтів сольового режиму едафотопу, а також омбро-, кріо- та терморежимів клімату. На основі проведеного фітоіндикаційного аналізу з'ясовані екологічні оптимуми угруповань по відношенню до провідних факторів середовища. Здійснені дослідження доповнюють інформацію щодо наявності та поширення на території України асоціацій Digitarietum ischaemii, Setario viridis-Erigeronetum canadensis i Ambrosietum artemisifoliae. Запропонована синтаксономічна схема має стати основою типологічних розробок для стратегічного планування та практичного впровадження заходів з оптимізації міського середовища та збалансованого розвитку Києвської міської агломерації.

Ключові слова: ординація. фітоіндикація, синтаксономія, урбоекосистеми, Україна 


\begin{tabular}{|c|c|c|c|c|c|c|c|c|c|c|c|c|c|c|c|c|c|c|c|c|c|c|c|c|}
\hline Number of association & 1 & 2 & 3 & 4 & 5 & 6 & 7 & 8 & 9 & 10 & 11 & 12 & 13 & 14 & 15 & 16 & 17 & 18 & 19 & 20 & 21 & 22 & 23 & 24 \\
\hline Numbers of relevés & 7 & 6 & 7 & 8 & 22 & 5 & 33 & 9 & 27 & 3 & 2 & 5 & 2 & 5 & 56 & 7 & 28 & 61 & 90 & 9 & 16 & 3 & 7 & 6 \\
\hline Amaranthus retroflexus & 46,2 & - & - & - & - & - & - & - & - & - & - & - & - & - & - & - & - & - & - & - & - & - & - & - \\
\hline Digitaria ischaemum & - & - & - & 93,1 & - & - & - & - & - & - & - & - & - & - & - & - & - & - & - & - & - & - & - & - \\
\hline Medicago sativa & - & - & - & 45,3 & - & - & - & - & - & - & - & - & - & - & - & - & - & - & - & - & - & - & - & - \\
\hline Bromus squarrosus & - & - & - & 40,1 & - & - & - & - & - & - & - & - & - & - & - & - & - & - & - & - & - & - & - & - \\
\hline Crepis rhoeadifolia & - & - & - & 38,8 & - & - & - & - & - & - & - & - & - & - & - & - & - & - & - & - & - & - & - & - \\
\hline Xanthium strumarium s.1. & - & - & - & - & 27 & - & - & - & - & - & - & - & - & - & - & - & - & - & - & - & - & - & - & - \\
\hline Cynodon dactylon & - & - & - & - & - & 100 & - & - & - & - & - & - & - & - & - & - & - & - & - & - & - & - & - & - \\
\hline Digitaria sanguinalis & - & - & - & - & - & - & 54,6 & - & - & - & - & - & - & - & - & - & - & - & - & - & - & - & - & - \\
\hline Festuca ovina s.l. & - & - & - & - & - & - & 38,3 & - & - & - & - & - & - & - & - & - & - & - & - & - & - & - & - & - \\
\hline Amaranthus albus & - & - & - & - & - & - & - & 78,1 & - & - & - & - & - & - & - & - & - & - & - & - & - & - & - & - \\
\hline Erysimum cheiranthoides & - & - & - & - & - & - & - & 66,7 & - & - & - & - & - & - & - & - & - & - & - & - & - & - & - & - \\
\hline Lepidium ruderale & - & - & - & - & - & - & - & 42,4 & - & - & - & - & - & - & - & - & - & - & - & - & - & - & - & - \\
\hline Tribulus terrestris & - & - & - & - & - & - & - & - & 36,7 & - & - & - & - & - & - & - & - & - & - & - & - & - & - & - \\
\hline Linaria vulgaris & - & - & - & - & - & - & - & - & - & - & 81,9 & - & - & - & - & - & - & - & - & - & - & - & - & - \\
\hline Fallopia convolvulus & - & - & - & - & - & - & - & - & - & - & 74,8 & - & - & - & - & - & - & - & - & - & - & - & - & - \\
\hline Atriplex prostrata & - & - & - & - & - & - & - & - & - & - & - & 83,1 & - & - & - & - & - & - & - & - & - & - & - & - \\
\hline Parthenocissus quin & - & - & - & - & - & - & - & - & - & - & - & - & 96,2 & - & - & - & - & - & - & - & - & - & - & - \\
\hline Atriplex sagittata & - & - & - & - & - & - & - & - & - & - & - & - & 87,7 & - & - & - & - & - & - & - & - & - & - & - \\
\hline Atriplex tatarica & - & - & - & - & - & - & - & - & - & - & - & - & - & 80,5 & - & - & - & 19 & - & - & - & - & - & - \\
\hline Glechoma hederacea & - & - & - & - & - & - & - & - & - & - & - & - & - & - & 26,2 & - & - & - & - & - & - & - & - & - \\
\hline Kochia scoparia & - & - & - & - & - & - & - & - & - & - & - & - & - & - & - & 89 & - & - & - & - & - & - & - & - \\
\hline Oenothera biennis s.l. & - & - & - & - & - & - & - & - & - & - & - & - & - & - & - & - & 29,3 & - & - & - & - & - & - & - \\
\hline Anisantha tectorum & - & - & - & - & - & - & - & - & - & - & - & - & - & - & - & - & - & 44,1 & - & - & - & - & - & - \\
\hline Hordeum murinum & - & - & - & - & - & - & - & - & - & - & - & - & - & - & - & - & - & - & 51,6 & - & - & - & - & - \\
\hline Poa aпnиа & - & - & - & - & - & - & - & - & - & - & - & - & - & - & - & - & - & - & - & 56 & - & - & - & - \\
\hline Tripleurospermum inodorum & - & - & - & - & - & - & - & - & - & - & - & - & - & - & - & - & - & - & - & 47,8 & 34,1 & - & - & - \\
\hline Trifolium repens & - & - & - & - & - & - & - & - & - & - & - & - & - & - & - & - & - & - & - & 32 & - & - & - & - \\
\hline Cyclachaena xanthiifolia & - & - & - & - & - & - & - & - & - & - & - & - & - & - & - & - & - & - & - & - & - & 90,6 & - & - \\
\hline Artemisia vulgaris & - & - & - & - & - & - & - & - & - & - & - & - & - & - & - & - & - & - & - & - & - & 52,2 & - & - \\
\hline Diplotaxis tenuifolia & - & - & - & - & - & - & - & - & - & - & - & - & - & - & - & - & - & 8,5 & - & - & - & - & 58,9 & - \\
\hline Berteroa incana & - & - & - & - & - & - & - & - & - & - & - & - & - & - & - & - & - & - & - & - & - & - & 41,5 & - \\
\hline Picris hieracioides & - & - & - & - & - & - & - & - & - & - & - & - & - & - & - & - & - & - & - & - & - & - & 29,9 & - \\
\hline Bromopsis inermis & - & - & - & - & - & - & - & - & - & - & - & - & - & - & - & - & - & - & - & - & - & - & - & 57 \\
\hline Carex caryophyllea & - & - & - & - & - & - & - & - & - & - & - & - & - & - & - & - & - & - & - & - & - & - & - & 51,2 \\
\hline Echinochloa crus-galli & - & 68,2 & - & - & - & - & - & 60 & - & - & - & - & - & - & - & - & - & - & - & - & - & - & - & - \\
\hline Setaria viridis & 25,3 & 27,4 & 35 & - & - & - & - & - & - & - & - & - & - & - & - & - & - & - & - & - & - & - & - & - \\
\hline Phalacroloma аппиит s.l. & - & - & - & 33,4 & - & 47,3 & - & - & - & - & - & - & - & - & - & - & - & - & - & - & - & - & - & - \\
\hline Setaria pumila & - & - & - & - & - & - & - & - & 17,4 & - & - & - & - & - & - & - & - & - & - & - & 25,1 & - & - & - \\
\hline Potentilla argentea & - & - & - & - & - & - & - & - & - & - & - & - & - & - & - & - & - & - & - & - & - & - & 43 & - \\
\hline Ambrosia artemisiifolia & - & - & - & - & 26,6 & - & - & - & - & - & - & - & - & - & - & - & 26,6 & - & - & - & - & - & - & - \\
\hline Lolium perenne & - & - & - & - & - & - & - & 43,9 & - & - & - & - & - & - & - & - & - & - & - & 32,2 & - & - & - & - \\
\hline Portulaca oleracea s.l. & - & - & - & - & - & - & - & - & 36,6 & - & - & 36,6 & - & - & - & - & - & - & - & - & - & - & - & - \\
\hline Sisymbrium loeselii & - & - & - & - & - & - & - & - & - & - & - & - & - & - & - & - & - & - & - & 27,1 & - & - & - & 68 \\
\hline Salsola tragus & - & - & - & - & - & - & - & - & - & 78,5 & - & - & - & - & - & - & - & - & - & - & - & - & - & - \\
\hline Chenopodium album s.l. & - & - & - & - & 25 & - & - & - & - & - & - & - & - & - & 25 & - & - & - & - & - & - & - & - & - \\
\hline Convolvulus arvensis & - & - & - & - & - & - & - & - & - & - & - & - & - & - & - & - & - & - & - & - & 25,1 & - & - & - \\
\hline Lactuca serriola & - & - & - & - & - & - & - & - & - & - & - & - & - & - & - & - & - & - & 19,1 & - & 39,1 & - & - & - \\
\hline Conyza canadensis & - & - & - & - & - & - & - & - & - & - & - & - & - & - & - & - & - & - & - & - & 28,7 & - & - & - \\
\hline
\end{tabular}

Number marks the associations: 1 - Amarantho retroflexi-Setarietum glancae; 2 - Echinochloo-Setarietum pumilae; 3 - Setario viridis-Erigeronetum canadensis; 4 Digitarietum ischaemii; 5 - Ambrosio artemisiifoliae-Chenopodietum albi; 6 - Cynodontetum dactyli; 7 - Digitario sanguinalis-Eragrostietum minoris; 8 - EragrostioAmaranthetum albi; 9 - Portulacetum oleracei; 10 - Salsoletum ruthenicae; 11 - Fallopio convolvuli-Chenopodietum albi; 12 - Atriplicetum hastatae; 13 - Atriplicetum nitentis; 14 - Atriplicetum tataricae; 15 - Chenopodietum stricti; 16 - Kochietum densiflorae; 17 - Ambrosietum artemisiifoliae; 18 - Brometum tectorum; 19 - Hordeetum murini; 20 - Hyoscyamo nigri-Malvetum neglectae; 21 - Erigeronto-Lactucetum serriolae; 22 - Ivaetum xanthiifoliae; 23 - Lactuco serriolae-Diplotaxietum tenuifoliae; 24 - Sisymbrietum loeselii 